\title{
Spectroscopic and reactivity comparisons between nonheme oxoiron(IV) and oxoiron(V) species bearing the same ancillary ligand
}

\author{
Valeria Dantignana, ${ }^{\mathrm{a}}$ Joan Serrano-Plana, ${ }^{\mathrm{a}}$ Apparao Draksharapu, ${ }^{\mathrm{b}}$ Carla Magallón, ${ }^{\mathrm{a}}$ Saikat Banerjee, ${ }^{\mathrm{b}}$ \\ Ruixi Fan, ${ }^{c}$ Ilaria Gamba, ${ }^{a}$ Yisong Guo, ${ }^{c}$ Lawrence Que Jr., ${ }^{\text {b* }}$ Miquel Costas, ${ }^{\text {a* }}$ Anna Company ${ }^{{ }^{*}}$
}

\begin{abstract}
a Institut de Química Computacional i Catàlisi (IQCC), Departament de Química, Universitat de Girona, C/ M. Aurèlia Capmany 69, 17003 Girona, Catalonia (Spain). E-mail: miquel.costas@udg.edu; anna.company@udg.edu

b Department of Chemistry and Center for Metals in Biocatalysis, University of Minnesota, Minneapolis MN 55455 (USA). E-mail: larryque@umn.edu

c Department of Chemistry, Carnegie Mellon University, 4400 Fifth Avenue, Pittsburgh, Pennsylvania 15213 (USA)
\end{abstract}

\section{Current addresses:}

A. Draksharapu: SL-208A, Department of Chemistry, Indian Institute of Technology Kanpur, Kanpur 208016, India.

J. Serrano-Plana: Department of Chemistry, University of Basel, Mattenstrasse 24a, BPR 1096

\begin{abstract}
This work directly compares the spectroscopic and reactivity properties of an oxoiron(IV) and an oxoiron(V) complex that are supported by the same neutral tetradentate $\mathrm{N}$-based $\mathrm{PyNMe}_{3}$ ligand. $\mathrm{A}$ complete spectroscopic characterization of the oxoiron(IV) species (2) reveals that this compound exists as a mixture of two isomers. The reactivity of the thermodynamically more stable oxoiron(IV) isomer (2b) is directly compared to that exhibited by the previously reported 1e-oxidized analogue $\left[\mathrm{Fe}^{\vee}(\mathrm{O})(\mathrm{OAc})\left(\mathrm{PyNMe}_{3}\right)\right]^{2+}(\mathbf{3})$. Our data indicates that $\mathbf{2 b}$ is $\mathbf{4}$ to 5 orders of magnitude slower than $\mathbf{3}$ in hydrogen atom transfer (HAT) from C-H bonds. The origin of this huge difference lies in the strength of the $\mathrm{O}-\mathrm{H}$ bond formed after HAT by the oxoiron unit, the $\mathrm{O}-\mathrm{H}$ bond derived from 3 being about $20 \mathrm{kcal} \cdot \mathrm{mol}^{-1}$ stronger than that from $\mathbf{2 b}$. The estimated bond strength of the $\mathrm{Fe}^{\mathrm{IV}} \mathrm{O}-\mathrm{H}$ bond of $100 \mathrm{kcal} \cdot \mathrm{mol}^{-1}$ is very close to the reported values for highly active synthetic models of compound I of cytochrome P450. In addition, this comparative study provides direct experimental evidence that the lifetime of the carbon-centered radical that forms after the initial HAT by the high valent oxoiron complex depends on the oxidation state of the nascent $\mathrm{Fe}-\mathrm{OH}$ complex. Complex $\mathbf{2} \mathbf{b}$ generates longlived carbon-centered radicals that freely diffuse in solution, while $\mathbf{3}$ generates short-lived caged radicals that rapidly form product $\mathrm{C}-\mathrm{OH}$ bonds, so only 3 engages in stereoretentive hydroxylation reactions. Thus, the oxidation state of the iron center not only modulates the rate of HAT but also the rate of ligand rebound.
\end{abstract}




\section{Introduction}

High valent oxoiron species are the oxidizing agents in a variety of iron-dependent oxygenases. For example, in the heme enzyme cytochrome P450, a high-valent oxoiron(IV)-porphyrin radical (Cpd I) is responsible for the hydroxylation of aliphatic $\mathrm{C}-\mathrm{H}$ bonds and of arene moieties, ${ }^{1}$ as well as the epoxidation of olefins, among other reactions..$^{2-4}$ In Rieske oxygenases, a family of bacterial nonheme iron enzymes, ${ }^{5,6}$ a yet undetected oxoiron(V) species has been proposed as the oxidizing agent, ${ }^{7}$ while an $S=2$ oxoiron(IV) species breaks strong $\mathrm{C}-\mathrm{H}$ bonds via hydrogen atom transfer (HAT) in other non-heme oxygenases ${ }^{8}$ such as taurine dioxygenase,${ }^{9}$ prolyl hydroxylase,${ }^{10}$ tyrosine hydroxylase, ${ }^{11}$ phenyl alanine hydroxylase ${ }^{12}$ as well as in $\alpha$ ketoglutarate dependent halogenases. ${ }^{13-15}$ Due to the biological relevance of these high valent oxoiron compounds, intense research efforts have been devoted to the preparation of synthetic analogs that can reproduce both the structural properties and the reactivity of the biological systems. These synthetic models aim to provide detailed insight into the enzymatic mechanisms, and helpful information for the design of catalysts with potential application in environmentally friendly oxidation technologies. ${ }^{16-20}$

Resulting from these research efforts, a large number of synthetic oxoiron(IV) complexes has been described. ${ }^{16}$ The reported systems typically consist of iron complexes based on tetra- and pentadentate nitrogen-based ligands, although complexes incorporating $\mathrm{O}$-atom donors ${ }^{16,18}$ or organometallic moieties are also known. ${ }^{21}$ Reactivity studies have disclosed that in most cases these synthetic oxoiron(IV) complexes are competent to perform hydrogen-atom abstraction of weak $\mathrm{C}-\mathrm{H}$ bonds and oxygen atom transfer (OAT) to sulfides. Examples in which such species can break stronger $\mathrm{C}-\mathrm{H}$ bonds are scarce and moderate reaction rates are observed in most of these cases. ${ }^{22}$

In sharp contrast to the plentiful examples of well-defined synthetic oxoiron(IV) species, the preparation of the one-electron oxidized oxoiron( $\mathrm{V})$ analogs has remained elusive. This can be attributed to the higher oxidizing abilities of these species that make them especially reactive and thus difficult to trap. The first example of a non-porphyrinic oxoiron(V) complex was reported by Collins and coworkers using a tetraanionic macrocyclic tetramide ligand $(\mathrm{TAML}) .{ }^{23}\left[\mathrm{Fe}^{\vee}(\mathrm{TAML})(\mathrm{O})\right]^{-}$was characterized by several spectroscopic means and reactivity studies demonstrated that it was competent in OAT to sulfides and alkenes and in HAT from alkanes. ${ }^{23,24}$ The structurally related compound $\left[\mathrm{Fe}^{\mathrm{V}}(\mathrm{bTAML})(\mathrm{O})\right]^{-}$was reported a few years later and it exhibited remarkably higher stability at room temperature. ${ }^{25,26}$ Nevertheless, these oxoiron(V) species are far less reactive than cytochrome P450 Cpd I, ${ }^{27}$ which is considered as their biological heme analog, suggesting that the tetranionic character of TAML and related ligands attenuate the electrophilicity of the complex, significantly limiting their oxidation reactivity. 
It was recently reported that the reaction of peracids with the iron(II) complex bearing a neutral $\mathrm{N}$-based $\mathrm{PyNMe}_{3}$ ligand, $\left[\mathrm{Fe}^{\prime \prime}\left(\mathrm{PyNMe}_{3}\right)\left(\mathrm{CH}_{3} \mathrm{CN}\right)_{2}\right]^{2+} \quad(\mathbf{1}$, Scheme 1$)$, generates an oxoiron(V) species, $\left[\mathrm{Fe}^{\vee}(\mathrm{O})(\mathrm{OAc})\left(\mathrm{PyNMe}_{3}\right)\right]^{2+}(\mathbf{3}$, Scheme 1),,22,28 which exhibits fast reaction rates in the stereoretentive hydroxylation of unactivated $\mathrm{C}-\mathrm{H}$ bonds of alkanes ${ }^{5}$ and in the epoxidation of olefins, ${ }^{6}$ even approaching the values reported for P450 Cpd I. The exact electronic structure of $\mathbf{3}$ has been a matter of debate. Münck, Costas and Que, on the basis of a thorough spectroscopic data, describe the species as an oxoiron(V) core attached to carboxylate ligand, generated after heterolytic O-O cleavage of a cyclic iron(III)-peracetate moiety. ${ }^{28}$ In contrast, Ye, Neese and coworkers claim that the compound is best characterized as an iron(IV) center antiferromagnetically coupled to an $\mathrm{O}-\mathrm{O}$ radical, so that $\mathrm{O}-\mathrm{O}$ bond has not been completely broken. ${ }^{29}$ Thus, this is a fascinating molecule with a very intriguing electronic structure. However, the interest in compound $\mathbf{3}$ goes beyond its unique bonding structure, as it shows reaction rates and selectivity patterns fully congruent with those of related iron complexes used as efficient catalysts in $\mathrm{C}-\mathrm{H}$ and $\mathrm{C}=\mathrm{C}$ oxidation reactions. Indeed, low temperature EPR studies performed along the catalytic reactions of some of these related systems during catalysis display the transient formation of small $(<2 \%)$ amounts of species with the characteristic spectroscopic features of 3. ${ }^{30-33}$ This data strongly suggests that $\mathbf{3}$ may constitute a representative example of the oxidizing agents operating with these catalysts. ${ }^{20,34}$

In this work, the spectroscopic and reactivity properties of $\mathbf{3}$ are compared with those of its oxoiron(IV) counterpart $\left[\mathrm{Fe}^{\mathrm{IV}}(\mathrm{O})\left(\mathrm{PyNMe}_{3}\right)\left(\mathrm{CH}_{3} \mathrm{CN}\right)\right]^{2+}(2)$. This oxoiron(IV) species has been characterized by several spectroscopic techniques and, remarkably, two isomers can be identified. The HAT and OAT reactivity of the more thermodynamically stable isomer $(\mathbf{2} \mathbf{b}$, Scheme 1$)$ has been studied and compared to $\mathbf{3}$. By comparing the reactivity of these two complexes with the same tetradentate ligand architecture, the current work provides valuable insight into the impact of the iron oxidation state in defining the unusual reactivity properties of 3.

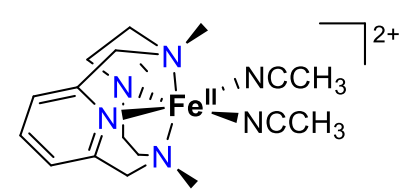

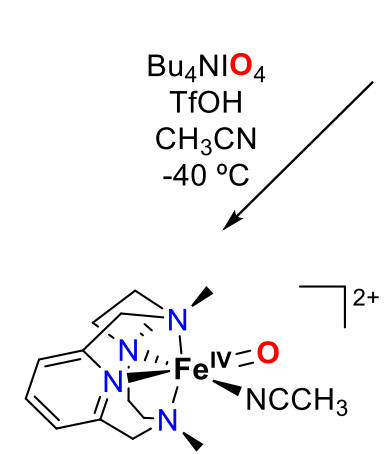

(2b)
(1)
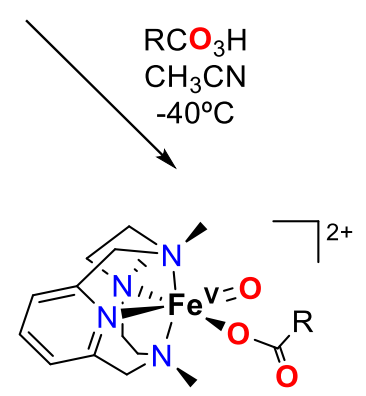

(3) 
Scheme 1. Structure for complex 1 and synthesis of the corresponding oxoiron(IV) (2b) and oxoiron(V) (3) complexes.

\section{Results and Discussion}

Synthesis and characterization of 2. The oxoiron(IV) complex $\left[\mathrm{Fe}^{\mathrm{IV}}(\mathrm{O})\left(\mathrm{PyNMe}_{3}\right)\left(\mathrm{CH}_{3} \mathrm{CN}\right)\right]^{2+}(2)$ can be prepared by reaction of the iron(II) precursor $\left[\mathrm{Fe}^{\prime \prime}\left(\mathrm{PyNMe}_{3}\right)\left(\mathrm{CH}_{3} \mathrm{CN}\right)_{2}\right]^{2+}(\mathbf{1})$ in $\mathrm{CH}_{3} \mathrm{CN}$ with either 1.1 equiv $\mathrm{Bu}_{4} \mathrm{NIO}_{4}$ or 4 equiv 2-tBuSO${ }_{2}-\mathrm{C}_{6} \mathrm{H}_{4} \mid \mathrm{O}$, albeit with low yields ( 40\%) as previously determined by Mössbauer spectroscopy. ${ }^{28}$ However, the addition of 0.8 equiv triflic acid $(\mathrm{TfOH})$ or 1 equiv $\mathrm{HClO}_{4}$ together with 1.1 equiv $\mathrm{Bu}_{4} \mathrm{NIO}_{4}$ to 1 affords the target complex 2 with significantly higher yields, as determined by the increased intensity of the two absorption bands characteristic of 2 at $\sim 800$ and $\sim 980 \mathrm{~nm} .{ }^{35}$

UV-vis spectral monitoring of the generation of $\mathbf{2}$ shows that the relative intensities of these two low energy bands change over time (Figure 1). Thus, the initially more intense $\sim 800 \mathrm{~nm}$ band decreases concomitantly with the increase in the intensity of the $\sim 980 \mathrm{~nm}$ band, which then becomes the more intense of the two nearIR bands (Figure 1). These observations suggest that two species are formed along the reaction pathway and an isosbestic point at $940 \mathrm{~nm}$ becomes apparent in the conversion between them. Interestingly, when the reaction of 1 with $1 \mathrm{O}_{4}^{-} / \mathrm{TfOH}$ is performed at $-60 \stackrel{\circ}{\circ} \mathrm{C}$ using a $1: 1 \mathrm{CH}_{3} \mathrm{CN}: \mathrm{CH}_{2} \mathrm{Cl}_{2}$ solvent mixture, the initial compound (2a) remains stable at this temperature. However, when the same reaction is carried out at $-20 \stackrel{\circ}{ }$, the direct formation of the second species (2b) is observed (Figure S8).

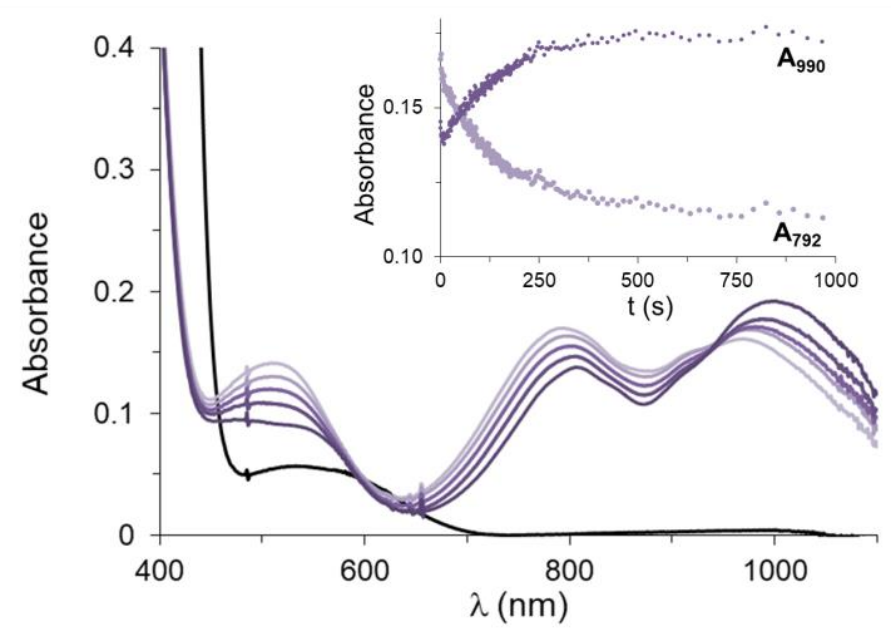

Figure 1. Spectral changes occurring upon reaction of a solution of 1 (1 mM, black line) in $\mathrm{CH}_{3} \mathrm{CN}$ with 1.1 equiv $\mathrm{Bu}_{4} \mathrm{NIO}_{4}$ and 0.8 equiv $\mathrm{TfOH}$ at $-40 \stackrel{\circ}{\circ} \mathrm{C}$. Two bands at $\sim 800$ and $\sim 980 \mathrm{~nm}$ are immediately formed upon mixing the reactants but their relative intensities changes over time. Inset: kinetic traces at 792 and $990 \mathrm{~nm}$. 
Spectroscopic analyses have been carried out in order to validate the iron oxidation states of $\mathbf{2 a}$ and $\mathbf{2 b}$ and characterize their electronic structures (Table 1). Mössbauer samples of the two species were prepared by freezing the reaction mixture of ${ }^{57} \mathrm{Fe}$-enriched 1 and the oxidant in $\mathrm{CD}_{3} \mathrm{CN}$ at $-40{ }^{\circ} \mathrm{C}$ to obtain samples of the initial and final species (2a and $\mathbf{2 b}$, Figure 2). Besides unavoidable high-spin ferric impurities that represented $\sim 35 \%$ of the samples, the Mössbauer spectra showed time-dependent patterns for the two species that can be clearly characterized by two doublets with different quadrupole splittings. While the sample obtained at reaction time $t=2$ min consists of $35 \%$ of the kinetically favored species $2 a$ and $30 \%$ of the thermodynamically favored species $\mathbf{2 b}, \mathbf{2 a}$ eventually converts into $\mathbf{2 b}$ at $t=30 \mathrm{~min}$. The Mössbauer parameters of species $\mathbf{2 b}(\delta$ $=0.09 \mathrm{~mm} / \mathrm{s}, \Delta \mathrm{EQ}_{\mathrm{Q}}=0.24 \mathrm{~mm} / \mathrm{s}$ ) are fully consistent with its assignment to an $\mathrm{S}=1$ oxoiron(IV) species previously reported by some of us. ${ }^{28}$ Interestingly, the initial species formed with $\lambda_{\max }$ at $\sim 800 \mathrm{~nm}(\mathbf{2 a})$ exhibits different Mössbauer parameters that are also consistent with an oxoiron(IV) species $\left(\delta=0.07 \mathrm{~mm} / \mathrm{s}, \Delta \mathrm{E}_{Q}=\right.$ $0.98 \mathrm{~mm} / \mathrm{s}$ ) with a larger $\Delta \mathrm{E}_{\mathrm{Q}}$ relative to $\mathbf{2} \mathbf{b}$. Several attempts to avoid contamination of $\mathbf{2} \mathbf{a}$ by $\mathbf{2} \mathbf{b}$ were carried out, but they all proved unsuccessful, perhaps because of the relatively low energy barrier for conversion of $2 a$ to $2 b$. 

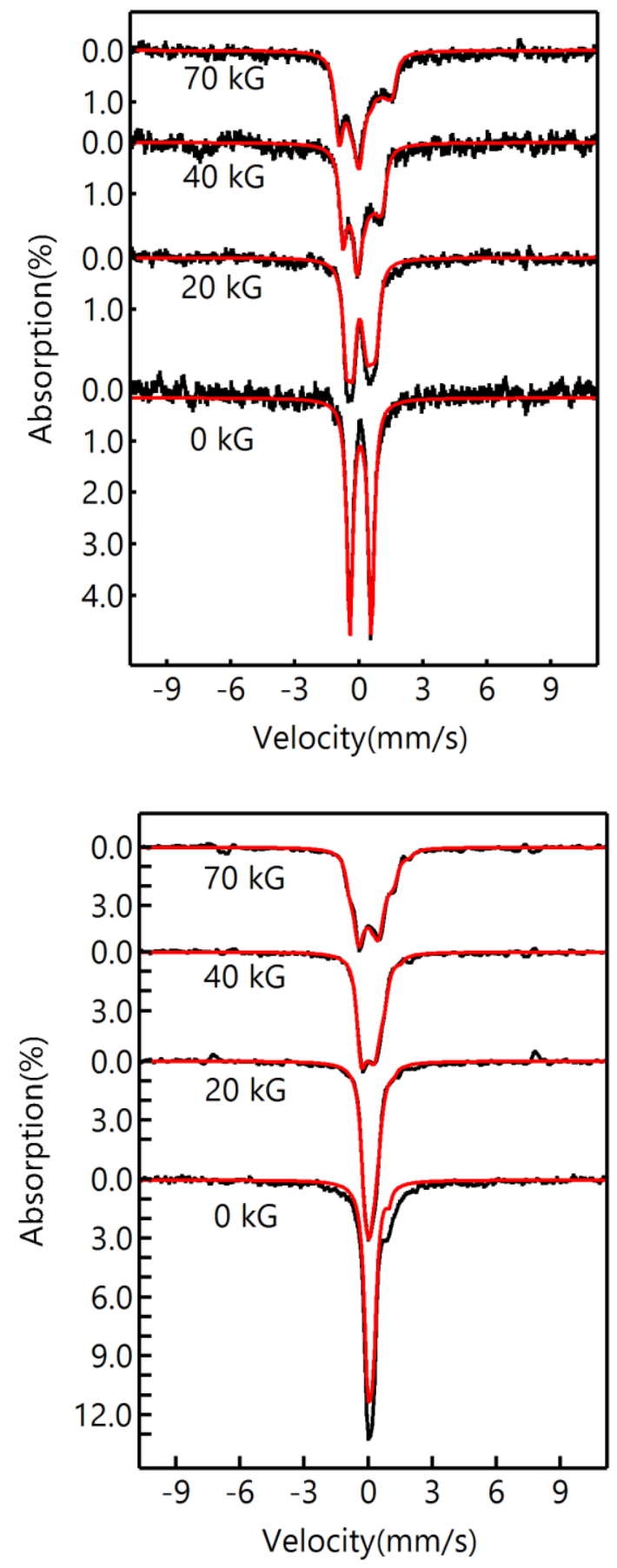

Figure 2. Mössbauer spectra of $\mathbf{2 a}$ and $\mathbf{2 b}$ at various temperatures and magnetic fields. The stacked spectra in the top panel were recorded from the sample frozen at $t=2 \mathrm{~min}$. The high-spin ferric species and species $\mathbf{2 b}$ have been removed to highlight the pattern for species $\mathbf{2 a}$ (35\% of total iron). The stacked spectra on the bottom panel were recorded from the sample frozen at $t=30 \mathrm{~min}$. The high-spin ferric species has been removed to highlight the pattern of species $\mathbf{2 b}$ ( $60 \%$ of total iron). Raw Mössbauer data can be found in Figure S6. 
Resonance Raman experiments $\left(\lambda_{\mathrm{exc}}=457 \mathrm{~nm}\right)$ of frozen acetonitrile solutions at $77 \mathrm{~K}$ also showed distinct parameters for $\mathbf{2} \mathbf{a}$ and $\mathbf{2 b}$ (Figure 3). A resonantly enhanced band at $822 \mathrm{~cm}^{-1}$ was observed for $\mathbf{2 a}$, while a Raman band at $829 \mathrm{~cm}^{-1}$ was observed for $\mathbf{2 b}$. Both values fall in the range of the $v(\mathrm{Fe}=0)$ modes $(798-862$ $\mathrm{cm}^{-1}$ ) previously measured for oxoiron(IV) species. ${ }^{36}$

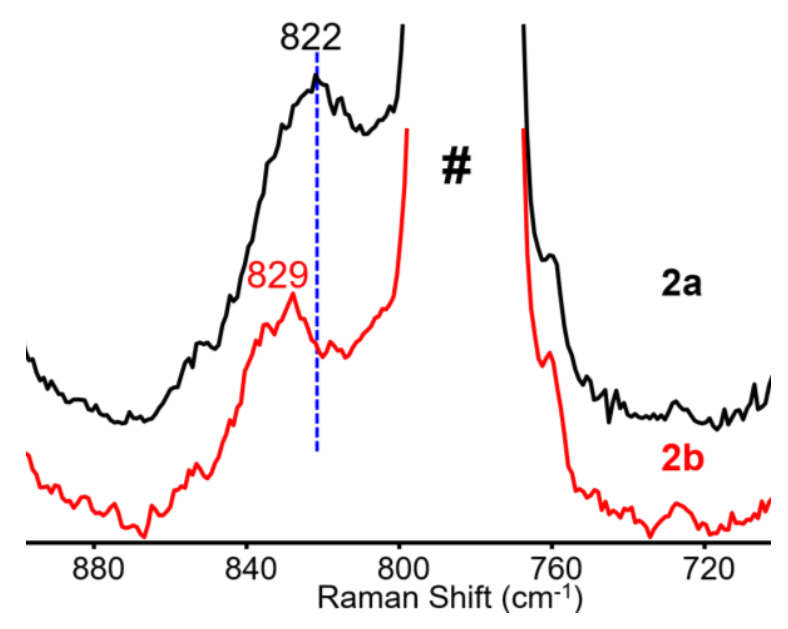

Figure 3. Resonance Raman spectra of $\mathbf{2 a}$ (black line) and $\mathbf{2 b}$ (red line) in frozen acetonitrile solutions at 77 $\mathrm{K}\left(\lambda_{\mathrm{exc}}=457 \mathrm{~nm}\right)$. Band marked with \# corresponds to solvent.

X-ray absorption spectroscopy (XAS) at $10 \mathrm{~K}$ was also used to characterize samples of $\mathbf{2 a}$ and $\mathbf{2 b}$ (Figure 4). The K-edge energies and pre-edge areas for samples of $\mathbf{2 a}$ and $\mathbf{2 b}$ were found to be $7124.8 \mathrm{eV} \& 20.9$ units and $7124.4 \mathrm{eV} \& 19.6$ units, respectively, in the typical range reported for $S=1 \mathrm{Fe}^{\mathrm{IV}}=\mathrm{O}$ complexes. ${ }^{36}$ The Fourier transformed EXAFS spectrum of $\mathbf{2 b}$ shows two major features at $\mathrm{R}+\Delta \sim 1.5$ and $2.4 \AA$ (Figure 4). The shell at $\mathrm{R}+\Delta \sim 1.5$ is best fit with a $0.8 \mathrm{O}$ scatterer at $1.65 \AA$ that is typical for an $\mathrm{Fe}=\mathrm{O}$ unit and $5 \mathrm{~N} / \mathrm{O}$ scatterers at $2.0 \AA$ arising from the ligand $\mathrm{PyNMe}_{3}$ and probably from a coordinated $\mathrm{CH}_{3} \mathrm{CN}$. The latter shell is best fit with $\mathrm{C}$ scatterers at 2.9 and $3.04 \AA$ that typically arise from pyridine containing ligands. The average Fe-N distance of $2.0 \AA$ is as expected to an $S=1 \mathrm{Fe}^{\mathrm{IV}}=\mathrm{O}$ species ${ }^{37}$ Species $2 \mathrm{a}$ exhibits bond metrics similar to $\mathbf{2} \mathbf{b}$ and the results are summarized in Table S3. Not surprisingly, XAS spectroscopy does not distinguish between the different compounds. 


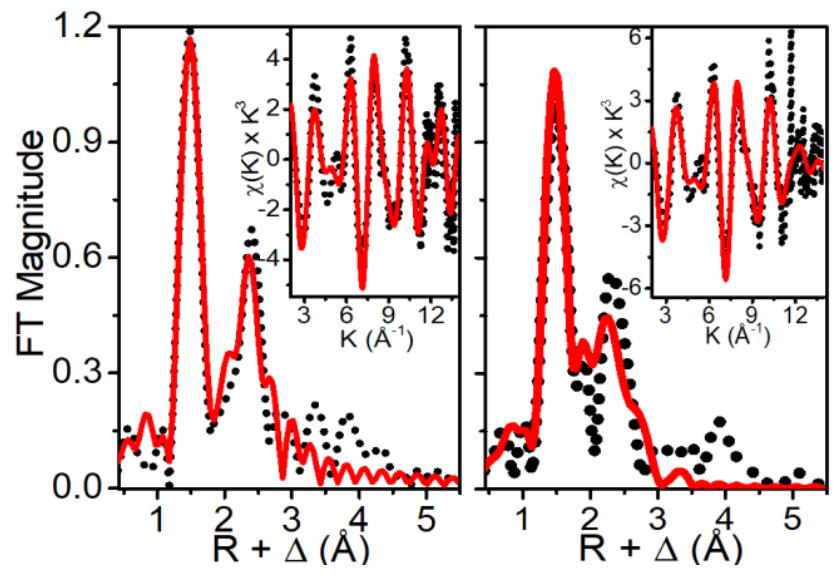

Figure 4. Fourier-transformed $k$-space EXAFS data of $\mathbf{2 a}$ (left) and $\mathbf{2 b}$ (right) in acetonitrile at $10 \mathrm{~K}$. Insets show the $k$-space spectra.

Table 1. Summary of spectroscopic data for $\mathbf{2 a}, \mathbf{2 b}$ and $\mathbf{3}$.

\begin{tabular}{lllll}
\hline & & $\mathbf{2 a}$ & $\mathbf{2 b}$ & $\mathbf{3}^{\mathrm{c}}$ \\
\hline UV-vis-NIR & $\lambda_{\max , \mathrm{nm}\left(\varepsilon, \mathrm{M}^{-1} \mathrm{~cm}^{-1}\right)}$ & $792(-)^{\mathrm{a}}$ & $805(230)^{\mathrm{b}}$ & $490(4500)^{\mathrm{b}}$ \\
& & $970(-)^{\mathrm{a}}$ & $990(320)^{\mathrm{b}}$ & $680(\mathrm{sh})$ \\
Mössbauer & $\delta, \mathrm{mm} / \mathrm{s}\left(\Delta \mathrm{E}_{\mathrm{Q}}, \mathrm{mm} / \mathrm{s}\right)$ & $0.07(0.98)$ & $0.09(0.24)$ & $-0.06(1.00)$ \\
rRaman & $v(\mathrm{Fe}-\mathrm{O}), \mathrm{cm}^{-1}$ & 822 & 829 & 815 \\
XAS & K-edge energy, eV & 7124.8 & 7124.4 & 7124.8 \\
& pre-edge energy, eV & 7114.1 & 7114.0 & 7114.4 \\
& pre-edge area, units & 20.9 & 19.6 & 15.6 \\
& r(Fe=O), $\AA$ & 1.66 & 1.65 & 1.63 \\
& average $\mathrm{r}(\mathrm{Fe}-\mathrm{N}), \AA$ & 2.00 & 2.00 & $1.97^{\mathrm{d}}$ \\
\hline
\end{tabular}

${ }^{a}$ Reliable extinction coefficient for $\mathbf{2 a}$ could not be obtained due to the unavoidable contamination of this compound by 2b.

${ }^{b}$ Extinction coefficient values $(\varepsilon)$ determined from the purity calculated by Mössbauer (for $\mathbf{2 b}$ ) or EPR analyses (for $\mathbf{3}$ ).

c Spectroscopic data for 3 was obtained from refs 22 and 28. Mössbauer and XAS parameters were obtained from samples of $\mathbf{3}$ generated using cyclohexyl peroxycarboxylic acid instead of peracetic acid.

${ }^{\mathrm{d}} \mathrm{A}$ second $\mathrm{Fe}-\mathrm{N}$ subshell is observed at 2.17 $\AA$, which we assign to $\mathrm{Fe}-\mathrm{N}$ bonds of the diferric byproduct that represents $50 \%$ of the $\mathrm{Fe}$ in samples of 3 .

The two oxoiron(IV) complexes $\mathbf{2} \mathbf{a}$ and $\mathbf{2} \mathbf{b}$ may differ only in the nature of the ligand bound cis to the oxo atom, which may be the $\mathrm{CH}_{3} \mathrm{CN}$ solvent, a $\mathrm{CF}_{3} \mathrm{SO}_{3}{ }^{-}$anion or $\mathrm{IO}_{3}-/ \mathrm{IO}_{4}{ }^{-}$derived from the oxidant. In order to test the likelihood of anion binding, the reactants for the generation of the oxoiron(IV) species were modified: in one experiment the starting iron(II) complex $\mathbf{1}$ was replaced by $\left[\mathrm{Fe}^{\prime \prime}\left(\mathrm{PyNMe}_{3}\right)\left(\mathrm{CH}_{3} \mathrm{CN}\right)_{2}\right]\left(\mathrm{SbF}_{6}\right)_{2}\left(\mathbf{1} \cdot \mathbf{S b F}_{\mathbf{6}}\right)$, which does not provide any coordinating anion, and in another experiment 2- $t \mathrm{BuSO}_{2}-\mathrm{C}_{6} \mathrm{H}_{4} \mathrm{IO}$ was used as an oxidant instead of $\mathrm{Bu}_{4} \mathrm{NIO}_{4}$. In both cases, isomer $2 \mathbf{a}$ is still initially formed and then evolves to $\mathbf{2 b}$ in $\mathrm{CH}_{3} \mathrm{CN}$ at $-40{ }^{\circ} \mathrm{C}$ (Figures $\mathrm{S} 10$ and $\mathrm{S} 11$ ). Thus, $\mathrm{CF}_{3} \mathrm{SO}_{3}{ }^{-}, \mathrm{IO}_{3}{ }^{-}$or $\mathrm{IO}_{4}{ }^{-}$coordination can be ruled out as the rationale for having two different oxoiron(IV) species, and a $\mathrm{CH}_{3} \mathrm{CN}$ solvent molecule is the most likely to be bound to the labile site in $\mathbf{2 a}$ and $\mathbf{2} \mathbf{b}$. The inequivalence of the two positions available for oxo coordination to the iron center, one 
trans to the pyridine and the other trans to an $\mathrm{N}$-methyl group (see Scheme $2 \mathrm{~b}$ ) easily rationalizes the existence of two geometrical isomers. Thus $2 \mathrm{a}$ would be the kinetically favored geometric isomer that then evolves to the thermodynamic product $\mathbf{2} \mathbf{b}$. The existence of two geometrical isomers of oxoiron(IV) compounds with tetradentate ligands has been discussed in previous systems, but spectroscopic characterization of the two species has only been achieved with the equatorially bound tetramethylcyclam (TMC) ligand. ${ }^{38-40}$

a)

$$
\mathrm{X}=\mathrm{CH}_{3} \mathrm{CN}, \mathrm{IO}_{3}^{-}, \mathrm{CF}_{3} \mathrm{SO}_{3}^{-}
$$

b)

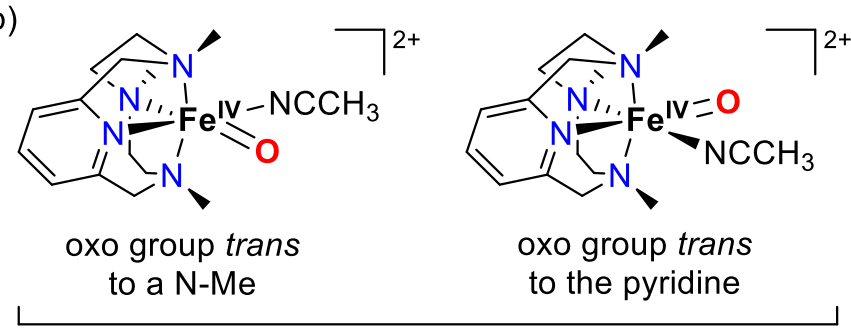

proposed structres for $\mathbf{2} \mathbf{a}$ and $\mathbf{2} \mathbf{b}$ isomers

Scheme 2. a) Different ligands $(X)$ can be coordinated cis to the oxo group in $\mathbf{2 a}$ and $\mathbf{2 b}$. b) Possible structure of the two geometrical isomers of the oxoiron(IV) species, $\mathbf{2} \mathbf{a}$ and $\mathbf{2} \mathbf{b}$.

Studies have shown that ${ }^{1} \mathrm{H}-\mathrm{NMR}$ spectroscopy can be a useful method for determining how the pyridine donors are bound relative to the $\mathrm{Fe}=\mathrm{O}$ unit. ${ }^{41,42,43}$ They could be coordinated either cis or trans to the oxo unit, and in the case of the cis-bound mode, the ring may be oriented parallel or perpendicular relative to the $\mathrm{Fe}=\mathrm{O}$ axis or somewhere in between (Table 2). Indeed we show below that this technique can distinguish between the two geometrical isomers of 2 , as the orientation of the pyridine with respect to the $\mathrm{Fe}=\mathrm{O}$ unit is different in the two options (Scheme 2b).

Table $2{ }^{1} \mathrm{H}$-NMR paramagnetic shifts observed for pyridine protons of oxoiron(IV) complexes (relative to

\begin{tabular}{|c|c|c|c|c|c|}
\hline Compound & $T(K)$ & $\bar{\beta}$ & $\beta^{\prime}$ & $\gamma$ & ref \\
\hline \multirow{2}{*}[\mathrm{Fe}^{\mathrm{IV}}(\mathrm{O})(\mathrm{N}4\mathrm{Py})]{$^{2+}$} & \multirow{2}{*}{298} & $\beta_{\|} 37$ & $\beta^{\prime}||-24$ & $Y_{\|} \mid 2.5$ & 41 \\
\hline & & $\beta_{\|} 23$ & $\beta^{\prime \prime \mid}-18$ & $Y_{\|} 1.3$ & \\
\hline \multirow{3}{*}[\mathrm{Fe}^{\mathrm{IV}}(\mathrm{O})(\mathrm{BnTPEN})]{$^{2+}$} & \multirow{3}{*}{298} & $\beta_{\|} 36$ & $\beta^{\prime} \|-22.3$ & $Y_{\|} 3.6$ & 41 \\
\hline & & $\beta_{\|} 33$ & $\beta_{\|}^{\prime}-21.7$ & $Y_{\|} 3.0$ & \\
\hline & & $\beta \perp-7.3$ & $\beta^{\prime} \perp-8.5$ & $Y \perp 1.4$ & \\
\hline
\end{tabular}
pyridine at $7 \mathrm{ppm})$. 


\begin{tabular}{lccccc}
\hline$\left[\mathrm{Fe}^{\mathrm{IV}}(\mathrm{O})\left(\mathrm{Py}_{2} \mathrm{MeTACN}\right)\right]^{2+}$ & 298 & $\begin{array}{c}\beta_{\|} 39 \\
\beta_{\perp}-8.4\end{array}$ & $\begin{array}{c}\beta^{\prime} \|-20 \\
\beta_{\perp}^{\prime}-5.5\end{array}$ & $\begin{array}{c}\mathrm{Y} \| 6.3 \\
\mathrm{Y}_{\perp} 4.2\end{array}$ & ${ }^{42}$ \\
\hline$\left[\mathrm{Fe}^{\mathrm{IV}}(\mathrm{O})(\mathrm{TMC}-\mathrm{py})\right]^{2+}$ & 298 & $\beta_{\text {trans }} 3.6,-0.5$ & $\mathrm{Ytrans}^{-11.6}$ & 44 \\
\hline$\left[\mathrm{Fe}^{\mathrm{IV}}(\mathrm{O})\left(\mathrm{PyNM}_{3}\right)\left(\mathrm{CH}_{3} \mathrm{CN}\right)\right]^{2+}(\mathbf{2 a})$ & 208 & -26 & 5 & this work \\
\hline$\left[\mathrm{Fe}^{\mathrm{V}}(\mathrm{O})\left(\mathrm{PyNMe}_{3}\right)\left(\mathrm{CH}_{3} \mathrm{CN}\right)\right]^{2+}(\mathbf{2 b})$ & 208 & 8 & -32 & this work \\
\hline
\end{tabular}

The ${ }^{1} \mathrm{H}-\mathrm{NMR}$ spectrum of the more stable $\mathbf{2} \boldsymbol{b}$ isomer recorded at $-65^{\circ} \mathrm{C}$ in $1: 1 \mathrm{CD}_{3} \mathrm{CN} / \mathrm{CD}_{2} \mathrm{Cl}_{2}$ exhibits relatively sharp and well-resolved paramagnetically shifted signals due to the $S=1 \mathrm{Fe}^{\mathrm{IV}}=\mathrm{O}$ center (Figure 5). The number of signals observed is consistent with the presence of a mirror plane of symmetry that bisects the pyridine ring. Due to their longer distances from the Fe center, the pyridine protons give rise to the sharpest signals in the spectrum of $\mathbf{2 b}$, which are found at $-25 \mathrm{ppm}(1 \mathrm{H})$ and $15 \mathrm{ppm}(2 \mathrm{H})$ (Figure 5). These peaks can be assigned respectively to the single $\gamma$ and the two $\beta$ protons of the pyridine based on their relative intensities. The remaining broader spectral features can be reasonably associated with benzylic $\mathrm{CH}_{2}$ (42 and -56 ppm), $\mathrm{N}-\mathrm{CH}_{2}(-35,-133 \mathrm{ppm})$ and $\mathrm{N}-\mathrm{CH}_{3}(-60 \mathrm{ppm})$ hydrogens, based on relative integrations of the resonances and by comparison to the ${ }^{1} \mathrm{H}-\mathrm{NMR}$ spectrum for the corresponding oxoiron(IV) species supported by the macrocyclic ligand with deuterated benzylic protons $\left(\mathbf{d}_{4}-\mathbf{2 b}\right)$ (Figure S7).

The chemical shift pattern observed for the pyridine $\beta$ and $\gamma$ protons of $\mathbf{2} \mathbf{b}$ can shed light on the orientation of the pyridine ligand relative to the $\mathrm{Fe}=\mathrm{O}$ unit, based on comparisons with the patterns associated with structurally well characterized $\mathrm{Fe}^{\mathrm{IV}}=\mathrm{O}$ complexes in the literature. ${ }^{43}$ Most published examples have pyridines bound cis to the $\mathrm{Fe}=\mathrm{O}$ unit and oriented parallel to the $\mathrm{Fe}=\mathrm{O}$ axis, namely $\left[\mathrm{Fe}^{\mathrm{IV}}(\mathrm{O})(\mathrm{N} 4 \mathrm{Py})\right]^{2+}$, $\left[\mathrm{Fe}^{\mathrm{IV}}(\mathrm{O})(\mathrm{BnTPEN})\right]^{2+} \quad$ and $\quad\left[\mathrm{Fe}^{\mathrm{IV}}(\mathrm{O})(\mathrm{MePy} 2 \mathrm{tacn})\right]^{2+} \quad(\mathrm{N} 4 \mathrm{Py} \quad=\quad \mathrm{N}, \mathrm{N}$-bis $(2-$ pyridyl-methyl $)-N$-bis $(2-$ pyridyl)methylamine; BnTPEN = N-benzyl- $N, N^{\prime}, N^{\prime}$-tris(2-pyridylmethyl)-1,2-diaminoethane; MePyztacn $=N$ methyl- $N$ ', $N$ "-bis(2-pyridylmethyl)-1,4,7-triazacyclononane). ${ }^{41,42,45}$ Such pyridine rings exhibit $\beta$ and $\beta$ ' protons respectively downfield and upfield shifted by $30-40 \mathrm{ppm}$ and $\gamma$ protons slightly downfield shifted from their respective diamagnetic positions. Besides having equatorial pyridines bound parallel to the $\mathrm{Fe}=\mathrm{O}$ unit, both $\left[\mathrm{Fe}^{\mathrm{IV}}(\mathrm{O})(\mathrm{BnTPEN})\right]^{2+}$ and $\left[\mathrm{Fe}^{\mathrm{IV}}(\mathrm{O})\left(\mathrm{Py}_{2} \mathrm{MeTACN}\right)\right]^{2+}$ have an additional pyridine bound cis to the $\mathrm{Fe}=\mathrm{O}$ unit but with the ring perpendicular to the $\mathrm{Fe}=\mathrm{O}$ unit. These pyridine donors exhibit smaller paramagnetic shifts of $\sim 10$ ppm upfield for the $\beta$ protons and 4-14 ppm downfield for the $\gamma$ proton. 


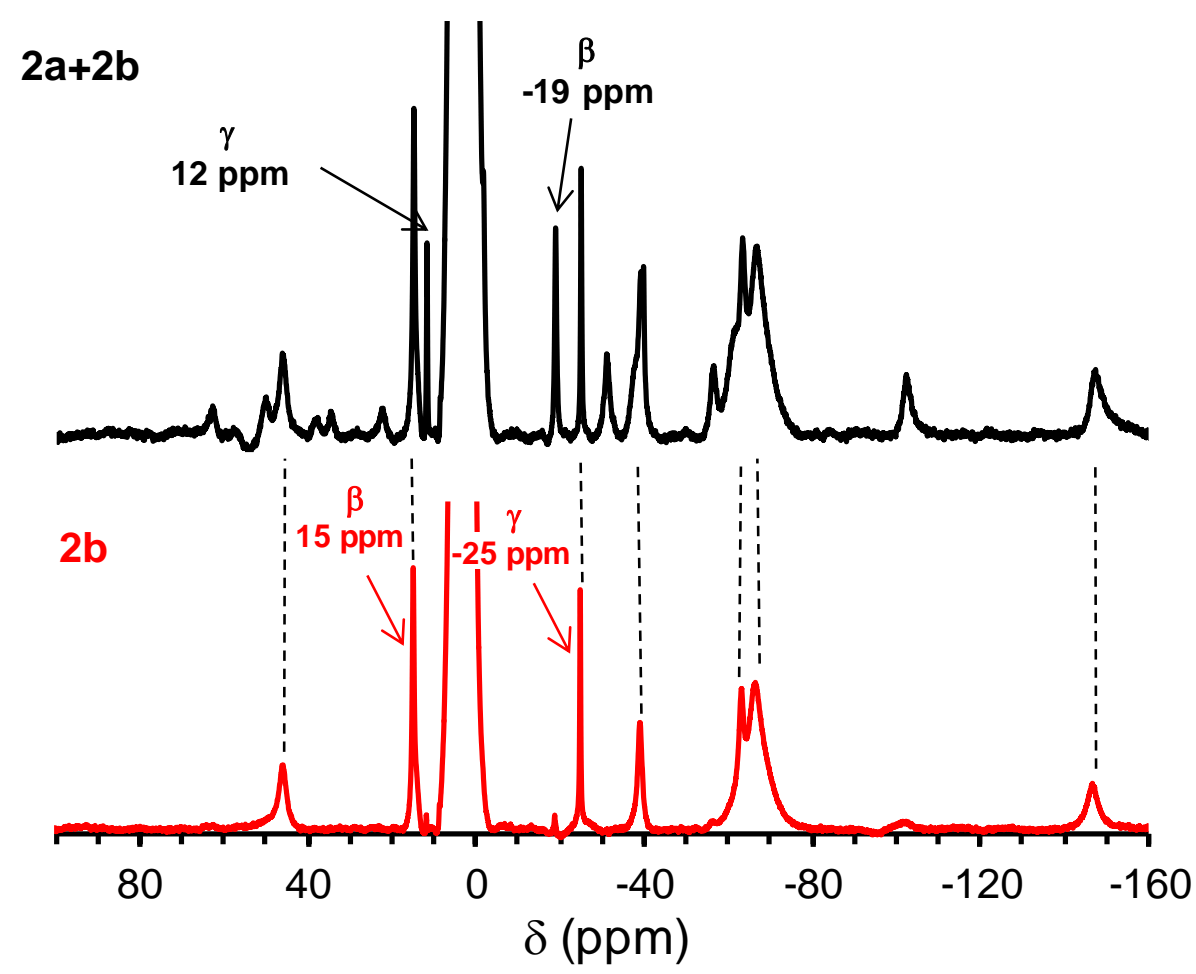

Figure 5. ${ }^{1} \mathrm{H}-\mathrm{NMR}$ spectra of a mixture of $\mathbf{2 a}$ and $\mathbf{2} \mathbf{b}$ (top) and $\mathbf{2 b}$ (bottom) in $1: 1 \mathrm{CD}_{3} \mathrm{CN} / \mathrm{CD}_{2} \mathrm{Cl}_{2}$ at $-65 \stackrel{\circ}{\circ}$. Pyridine $\beta(2 \mathrm{H})$ and $\gamma(1 \mathrm{H})$ protons are labeled in the figure. Other broader peaks for $\mathbf{2} \mathbf{b}$ are assigned as follows: benzylic protons at $46 \mathrm{ppm}(2 \mathrm{H})$ and $-63 \mathrm{ppm}(2 \mathrm{H})$, aliphatic $\mathrm{CH}_{2}$ peaks at $-39 \mathrm{ppm}(2 \mathrm{H})$ and $-147 \mathrm{ppm}(2 \mathrm{H})$, and $\mathrm{CH}_{3}$ protons at $-67 \mathrm{ppm}(9 \mathrm{H})$.

Neither of the shift patterns described above matches that observed for $\mathbf{2 b}$, which exhibits a relatively small downfield paramagnetic shift of $8 \mathrm{ppm}$ for the $\beta$ protons and a larger upfield paramagnetic shift of $32 \mathrm{ppm}$ for the $\gamma$ proton. Such a pattern is associated with a pyridine bound trans to the oxo atom, as reported for the pendant pyridine ligand trans to the $\mathrm{Fe}=\mathrm{O}$ unit in $\left[\mathrm{Fe}^{\mathrm{IV}}(\mathrm{O})(\mathrm{TMC}-\mathrm{py})\right]^{2+}(\mathrm{TMC}-\mathrm{py}=1$-(pyridyl-2-methyl)-4,8,11trimethyl-1,4,8,11-tetrazacyclotetradecane). ${ }^{44}$ For the latter complex, the two pyridine $\beta$ protons exhibit quite small paramagnetic shifts of -0.5 and $+3.6 \mathrm{ppm}$ (actual peaks observed at 6.5 and $10.6 \mathrm{ppm}$ ) and a larger paramagnetic shift of nearly $-11.6 \mathrm{ppm}$ for the $\gamma$ proton found at $-4.6 \mathrm{ppm}$. Although there is a difference in the magnitudes of the paramagnetic shifts of the pyridine protons between these two complexes, the directions of the shifts agree. The larger paramagnetic shifts observed for $\mathbf{2 b}$ versus $\left[\mathrm{Fe}^{\mathrm{IV}}(\mathrm{O})(\mathrm{TMC}-\mathrm{py})\right]^{2+}(\mathrm{Table} 2)$ likely arise from two factors: a) the $90^{\circ} \mathrm{C}$ difference in temperature at which the NMR data were obtained, which will decrease when this difference is taken into account and b) the shorter Fe- $\mathrm{N}_{\text {py }}$ bond length of $2.03 \AA$ calculated for $\mathbf{2 b}$ (see Supporting information for more details, Figure S27) versus the 2.118(3)- $\AA$ value determined 
crystallographically for $\left[\mathrm{Fe}^{\mathrm{IV}}(\mathrm{O})(\mathrm{TMC}-\mathrm{py})\right]^{2+}$, which results in greater unpaired spin density delocalized onto the pyridine in the former. ${ }^{46}$

The ${ }^{1} \mathrm{H}-\mathrm{NMR}$ spectrum of $2 \mathrm{a}$ in $1: 1 \mathrm{CD}_{3} \mathrm{CN}: \mathrm{CD}_{2} \mathrm{Cl}_{2}$ at $-65{ }^{\circ} \mathrm{C}$ shows significant contamination from the more stable $\mathbf{2 b}$ isomer, as shown by the Mössbauer results discussed earlier (Figure 2). Based on the above assignment of $\mathbf{2} \mathbf{b}$ as the trans isomer, $\mathbf{2} \mathbf{a}$ should correspond to the cis isomer with the pyridine perpendicular to the $\mathrm{Fe}=\mathrm{O}$ axis. From a careful inspection of the composite $\mathbf{2} \mathbf{a}+\mathbf{2} \mathbf{b}$ spectrum and comparison with the spectrum of pure $\mathbf{2 b}$, we can identify sharper features with a relative $2: 1$ intensity ratio at -19 ppm and 12 ppm that we assign to the $\beta$ and $\gamma$ protons of $\mathbf{2 a}$, respectively. The shift pattern with upfield shifted $\beta$ protons and a downfield shifted $\gamma$ proton is fully consistent with a cis-bound pyridine perpendicular to the $\mathrm{Fe}=\mathrm{O}$ unit (Scheme $2 b)$, as found for the pyridines perpendicular to the $\mathrm{Fe}=\mathrm{O}$ units of $\left[\mathrm{Fe}^{\mathrm{IV}}(\mathrm{O})(\mathrm{BnTPEN})\right]^{2+}$ and $\left[\mathrm{Fe}^{\mathrm{IV}}(\mathrm{O})(\mathrm{Py} 2 \mathrm{MeTACN})\right]^{2+}($ Table 2$) .{ }^{41,42}$

Interestingly, in line with the experimental observations, DFT calculations predict that the isomer with the oxo group trans to the pyridine ring is slightly energetically favored (by $0.9 \mathrm{kcal} / \mathrm{mol}$ ) over the isomer with the oxo group cis to the pyridine (see Supporting Information for more details). This further supports the NMR results pointing out that the most stable isomer $\mathbf{2} \mathbf{b}$ contains the pyridine trans to the oxo group, and they show a relative cis orientation in the kinetically favored geometric isomer $\mathbf{2 a}$.

Oxidative reactivity of $2 a$ versus $2 b$ and comparison to 3 . The oxidizing abilities of $2 a$ and $2 b$ were compared at $-60{ }^{\circ} \mathrm{C}$. Isomer $2 \mathrm{a}$ was directly synthesized at $-60 \stackrel{\circ}{\circ} \mathrm{C}$ in $1: 1 \mathrm{CH}_{3} \mathrm{CN}: \mathrm{CH}_{2} \mathrm{Cl}_{2}$. Of note, this compound is obtained together with approximately equimolar amounts of isomer $\mathbf{2 b}$ according to spectroscopic studies (see above). Compound $\mathbf{2 b}$ was first generated at $-40 \stackrel{\circ}{\mathrm{C}}$ and then cooled down to $-60{ }^{\circ} \mathrm{C}$ for reactivity comparisons with $\mathbf{2 a}$. Reaction rates were determined by monitoring the decay of the near-IR absorption bands characteristic of $\mathbf{2 a}$ and $\mathbf{2 b}$ (at 792 and $990 \mathrm{~nm}$, respectively) upon addition of an excess of a particular substrate (Figure $\mathrm{S} 12$ and $\mathrm{S} 13$ ). In the case of $\mathbf{2 b}$, its decay at $990 \mathrm{~nm}$ could be fitted to single exponential functions, from which observed reaction rates $\left(k_{o b s}\right)$ and the corresponding second order rate constants $\left(k_{2}\right)$ could be extracted. Reactions of $2 \mathbf{a}$ with substrates were "contaminated" by the presence of approximately equimolar quantities of $\mathbf{2} \mathbf{b}$. Thus, the contribution of $\mathbf{2} \mathbf{b}$ to the decay of the most intense absorption band of $\mathbf{2 a}$ at $792 \mathrm{~nm}$ was subtracted to obtain the decay of "pure" compound 2a. Gratifyingly, the reaction of this species with substrates could also be nicely fitted to a single exponential function and reaction rates for 2 a could be extracted (see Supporting Information for more details). Both species exhibited hydrogen-atom transfer (HAT) and oxygen atom transfer (OAT) reactivity typically observed for most $S=1$ oxoiron(IV) complexes but they showed different reactivity trends. Isomer $\mathbf{2 a}$ reacted approximately 18 times faster than $\mathbf{2 b}$ in HAT reactions 
with 9,10-dihydroanthracene ( $k_{2}=9.5 \mathrm{M}^{-1} \mathrm{~s}^{-1}$ for $2 \mathrm{a}$ and $0.53 \mathrm{M}^{-1} \mathrm{~s}^{-1}$ for $\left.\mathbf{2 b}\right)$ but was about 4 times less reactive than $\mathbf{2 b}$ in OAT reactions with thioanisole $\left(k_{2}=0.038 \mathrm{M}^{-1} \mathrm{~s}^{-1}\right.$ for $\mathbf{2 a}$ and $0.14 \mathrm{M}^{-1} \mathrm{~s}^{-1}$ for $\left.\mathbf{2 b}\right)$. These results further support the notion that $\mathbf{2} \mathbf{a}$ and $\mathbf{2} \mathbf{b}$ correspond to two different oxoiron(IV) species that exhibit different relative reactivity.

Further reactivity studies of the oxorion(IV) species were carried out using isomer $\mathbf{2 b}$. On the one hand, this compound corresponds to the thermodynamic product, so that it can be obtained without contamination from $2 \mathbf{a}$ and is thermally stable at $-40 \stackrel{\circ}{ } \mathrm{C}$, which makes it easier to manipulate. On the other hand, the relative disposition of the oxo group trans to the pyridine in $\mathbf{2 b}$ is also observed in $\mathbf{3}$. For the latter, spectroscopic analysis did not show the presence of two different isomers, ${ }^{28}$ and the detected signals were assigned to the isomer with the oxo group trans to the pyridine as it was slightly more stable than the corresponding cis isomer on the basis of DFT calculations. Thus, $\mathbf{2} \mathbf{b}$ and $\mathbf{3}$ likely represent the same geometric isomer making reactivity comparisons more straightforward.

Firstly, the reactivity of $\mathbf{2} \mathbf{b}$ with thioanisole and its para-substituted derivatives ( $\mathrm{X}=\mathrm{OMe}, \mathrm{Me}, \mathrm{Cl}, \mathrm{CN})$ at -40 ${ }^{\circ} \mathrm{C}$ was evaluated. Upon substrate addition, the absorption bands associated with $\mathbf{2 b}$ disappeared (Figure $\mathrm{S} 14$ ), and this decay was also accompanied by the recovery of the UV-vis spectroscopic features of 1 (Figure S16), which was ascertained by MS (Figure S17). Moreover, analysis of the oxidized products in the reaction with thioanisole revealed the formation of the corresponding sulfoxide in $54 \%$ yield with respect to $\mathbf{2 b}$. Under conditions of excess substrate, the decay of the absorption band of $\mathbf{2} \mathbf{b}$ at $990 \mathrm{~nm}$ could be fitted to a single exponential and second-order rate constants could be extracted. As expected, the Hammett analysis supported the electrophilic character of $\mathbf{2} \mathbf{b}(\rho=-1.77$, Figure S15) as previously observed for other well-defined oxoiron(IV) complexes ${ }^{38,47}$ (see SI for more details). The reaction of the oxoiron(V) species $\mathbf{3}$ with sulfides is exceedingly fast, and reaction rates could not be determined even when analyzed at $-45 \stackrel{\circ}{\circ}$ by stopped flow methods.

Therefore, a direct comparison between the OAT ability of $\mathbf{2} \mathbf{b}$ and $\mathbf{3}$ cannot be made, but the accumulated data indicate that $\mathbf{2} \mathbf{b}$ behaves like a common oxoiron(IV) complex, while under the same reaction conditions 3 exhibits extraordinarily fast OAT rates. Under the assumption that the possible contributions of spin state changes to these reactions are either (i) insignificant or (ii) are very similar for the two compounds, the comparison highlights the extreme electrophilicity of the $\mathrm{Fe}^{\mathrm{v}}=\mathrm{O}$ unit.

The HAT ability of $\mathbf{2} \mathbf{b}$ was also measured by studying its reaction with hydrocarbons. In this case, kinetic studies were carried out at $-40 \stackrel{\circ}{ } \mathrm{C}$ in order to establish a direct comparison with the reaction rates reported for 3 at this temperature (see below). ${ }^{22}$ Substrates with relatively weak $\mathrm{C}-\mathrm{H}$ bonds $\left(\mathrm{BDE}=75-85 \mathrm{kcal} \cdot \mathrm{mol}^{-1}\right.$ ) 
were used, because substrates with stronger bonds turned out to be unreactive towards $\mathbf{2 b}$ at this temperature. Due to the limited solubility of the chosen substrates (xanthene, 1,4-cyclohexadiene, 9,10-dihydroanthracene, and fluorene) in $\mathrm{CH}_{3} \mathrm{CN}$ at $-40{ }^{\circ} \mathrm{C}$, reactions were run in a $1: 1 \mathrm{CH}_{3} \mathrm{CN}: \mathrm{CH}_{2} \mathrm{Cl}_{2}$ mixture. Reactions produce $\left[\mathrm{Fe}^{\prime \prime \prime}(\mathrm{OH})\left(\mathrm{CF}_{3} \mathrm{SO}_{3}\right)\left(\mathrm{PyNMe}_{3}\right)\right]^{+}$(ascertained by $\mathrm{MS}$, Figure S19) and organic products. Reactions were monitored by UV-vis absorption spectroscopy by following the decay of the band at $990 \mathrm{~nm}$ characteristic of 2b upon addition of the substrate (Figure S18). Under these experimental conditions reactions showed pseudo-first order behavior and second-order reaction rates $\left(k_{2}\right)$ could be extracted by plotting the observed rate constants $\left(k_{o b s}\right)$ as a function of the substrate concentration (Figure S20). These rate constants were then adjusted for the reaction stoichiometry to yield $k_{2}$ based on the number of abstractable hydrogen atoms of substrates. As expected, reaction rates decreased with the increase of the $\mathrm{C}-\mathrm{H} B D E$ and more interestingly the $\log \left(k_{2}^{\prime}\right)$ values correlated linearly with the C-H BDE values, giving a slope of approximately -0.25 (kcal $\left./ \mathrm{mol}\right)^{-}$ 1 (Figure S21).

HAT reactions with compound $\mathbf{2 b}$ also exhibit a normal kinetic isotope effect (KIE), so deuterated substrates react more slowly than their protio analogs. Using xanthene- $\mathrm{d}_{2}$ and 9,10-dihydroanthracene- $\mathrm{d}_{4}$, KIE values of 24 and 28 were obtained, respectively (Figure S23). ${ }^{48}$ These high values are commonly observed in HAT processes carried out by oxoiron(IV) complexes. For example, a KIE value of 36 (at - $40{ }^{\circ} \mathrm{C}$ ) was reported for the oxidation of xanthene with the oxoiron(IV) complex bearing the 13-TMC ligand ${ }^{49}$ and a KIE value of 27 (at $\left.-15^{\circ} \mathrm{C}\right)$ was described for the oxidation of 9,10-dihydroanthracene using the $\left[\mathrm{Fe}^{\mathrm{IV}}(\mathrm{O})\left(\mathrm{CH}_{3} \mathrm{CN}\right)(\mathrm{Pytacn})\right]^{2+}$ complex. ${ }^{38}$ Interestingly, these high KIE values are comparable to the large KIE determined for the $S=2$ oxoiron(IV) intermediate $\mathrm{J}$ in TauD (KIE 50 ). 50,51 Altogether, the good correlation between reaction rates and $\mathrm{C}-\mathrm{H}$ BDE values and the large KIE values provides strong evidence for a rate-determining HAT process in the reactions of hydrocarbons with $\mathbf{2 b}$.

Activation parameters for HAT reactions of $\mathbf{2} b$ with xanthene and cyclohexadiene were determined by measuring reaction rates between 273 and $233 \mathrm{~K}$. The corresponding Eyring plot for xanthene afforded $\Delta \mathrm{H}^{\neq}=$ $6.4 \pm 0.6 \mathrm{kcal} \cdot \mathrm{mol}^{-1}$ and $\Delta \mathrm{S}^{\neq}=-27.2 \pm 2.6 \mathrm{cal} \cdot \mathrm{K}^{-1} \cdot \mathrm{mol}^{-1}$, while $\Delta \mathrm{H}^{\neq}=7.3 \pm 0.5 \mathrm{kcal} \cdot \mathrm{mol}^{-1}$ and $\Delta \mathrm{S}^{\neq}=-25.6 \pm 2.1 \mathrm{cal} \cdot \mathrm{K}^{-}$ ${ }^{1} \cdot \mathrm{mol}^{-1}$ were determined for cyclohexadiene (Figure S24). These values are very close to the ones previously reported for the reaction of a tetracarbene ligated oxoiron(IV) with 1,4-cyclohexadiene and 9,10dihydroanthracene. ${ }^{52}$

It has been observed that the reactivity of oxoiron(IV) complexes depends dramatically on the ligand set.53-55 The combination of the above described data for $\mathbf{2 b}$ and the recently described reactivity of $\mathbf{3}^{22}$ represents a unique opportunity to compare the oxidizing abilities of a pair of oxoiron(IV) and oxoiron(V) compounds bearing 
exactly the same ligand architecture. A first notable observation is that reactions with substrates bearing strong C-H bonds (BDE $~ 89-100 \mathrm{kcal} \cdot \mathrm{mol}^{-1}$ ) can only be studied for $\mathbf{3}$ because $\mathbf{2} \mathbf{b}$ does not appear to be powerful enough to carry out HAT reactions with these strong $\mathrm{C}-\mathrm{H}$ bonds. On the other hand, rates for HAT reactions with substrates containing weak $\mathrm{C}-\mathrm{H}$ bonds can only be measured for $\mathbf{2 b}$, because the reaction with $\mathbf{3}$ exhibited extremely fast reaction rates, too fast even at $-40{ }^{\circ} \mathrm{C}$ to be extracted by stopped flow methods..$^{22}$ Therefore, reaction rates for a common substrate are not available.

In order to establish a quantitative comparison between reaction rates, we performed regression analyses of the $\log \left(k_{2}{ }^{\prime}\right)$ vs BDE correlations experimentally determined for $\mathbf{2 b}$ and $\mathbf{3}$. Regression analyses provide correlation lines with a slope of $-0.25(\mathrm{kcal} / \mathrm{mol})^{-1}$ in both cases (using a linear free energy relationship a unitless slope of 0.34 is obtained in both cases. Figures S22). This coincidence in the slopes of these correlations strongly suggests that HAT of $\mathbf{2 b}$ and $\mathbf{3}$ proceed via very similar transition states. Extrapolation of the straight lines obtained in these correlations permitted us to estimate hypothetical second order reaction rates for substrates containing strong $\mathrm{C}-\mathrm{H}$ bonds in the case of $\mathbf{2 b}$, and for the fast reactions of $\mathbf{3}$ against substrates with weak $\mathrm{C}-\mathrm{H}$ bonds. Results are shown in Figure 6 and Table 3. As anticipated, the gathered data show that $\mathbf{3}$ is four to five orders of magnitude more reactive than $\mathbf{2 b}$. It is important to note that extrapolation of the $\log \left(k_{2}^{\prime}\right)$ vs BDE correlations must be done with caution. While linear correlations over a wide range of BDEs have been reported for several oxoiron(IV) complexes with moderate reactivities, ${ }^{25,38,55,56}$ a loss of linearity below $90 \mathrm{kcal} / \mathrm{mol}$ has been observed for a highly reactive peroxygenase compound I and $t$-butoxyl radicals. ${ }^{27,57,58}$ Such a loss of linearity might not be discarded for the highly reactive oxoiron(V) species $\mathbf{3}$ for substrates with low BDEs, thus challenging the direct extrapolation at low BDEs for this compound. Thus, while loss of linearity may happen for compound $\mathbf{3}$ at low BDE values, this is not likely to occur at high BDEs for $\mathbf{2 b}$ according to literature precedents. This way, extrapolation of the straight line is reliable for $\mathbf{2 b}$ and the statement that $\mathbf{3}$ is four to five orders of magnitude more reactive than $\mathbf{2 b}$ can be more strongly defended for strong $\mathrm{C}-\mathrm{H}$ bonds.

Reactivity comparisons between oxoiron(IV) and oxoiron(V) species have been reported in very few systems. In fact, the only precedent for non-heme iron systems is for the complexes of the tetraanionic bTAML ligand. In this case, the reaction of $\left[\mathrm{Fe}^{\mathrm{V}}(\mathrm{O})(\mathrm{bTAML})\right]^{-}$towards benzyl alcohol $\left(\mathrm{BDE}<80 \mathrm{kcal} \cdot \mathrm{mol}^{-1}\right)$ at $\mathrm{pH} 7$ was found to be 2500 times faster than for its 1 -e-reduced counterpart $\left[\mathrm{Fe}^{\mathrm{IV}}(\mathrm{O})(\mathrm{bTAML})\right]^{2-}$ at $\mathrm{pH} 12 .{ }^{59} \mathrm{O}$ note, reactions towards stronger $\mathrm{C}-\mathrm{H}$ bonds were precluded due to the attenuated electrophilicity of this system. In contrast, van Eldik and coworkers found that a Cpd I mimic, $\left[\left(\text { TMPS }^{\bullet+}\right) \mathrm{Fe}^{\mathrm{IV}}(\mathrm{O})\left(\mathrm{H}_{2} \mathrm{O}\right)\right]^{3-}$, reacted with benzyl alcohols only a hundred times faster than its 1 -e-reduced counterpart $\left[(\mathrm{TMPS}) \mathrm{Fe}^{\mathrm{IV}}(\mathrm{O})(\mathrm{OH})\right]^{5-}$. The different degrees of 
protonation of the $\mathrm{OH} / \mathrm{OH}_{2}$ ligand in these two compounds should be noted. ${ }^{60}$ Even more interestingly, a Cpd I model compound reported by Groves [(4-TMPyP•+) $\left.\mathrm{Fe}^{\mathrm{IV}}(\mathrm{O})\right]^{+}$exhibited a very high second order rate constant of $3.6 \times 10^{6} \mathrm{M}^{-1} \mathrm{~S}^{-1}$ for the oxidation of xanthene, but negligible reactivity was observed when the 1-e-reduced analog [(4-TMPyP)Fe $\left.{ }^{I V}(O)\right]$ was used. ${ }^{61}$ Indeed, the extrapolated reaction rate for the oxidation of xanthene calculated for 3 (Table 3) is only 10 times slower than that observed for Groves' model compound without accounting for the $50^{\circ} \mathrm{C}$ difference in the measurements (reaction rates in the Groves' system were measured at $+10^{\circ} \mathrm{C}$, while reactions for 3 were recorded at $-40^{\circ} \mathrm{C}$ ), thus suggesting that 3 compares well in HAT reactivity with the most active cytochrome P450 mimics.

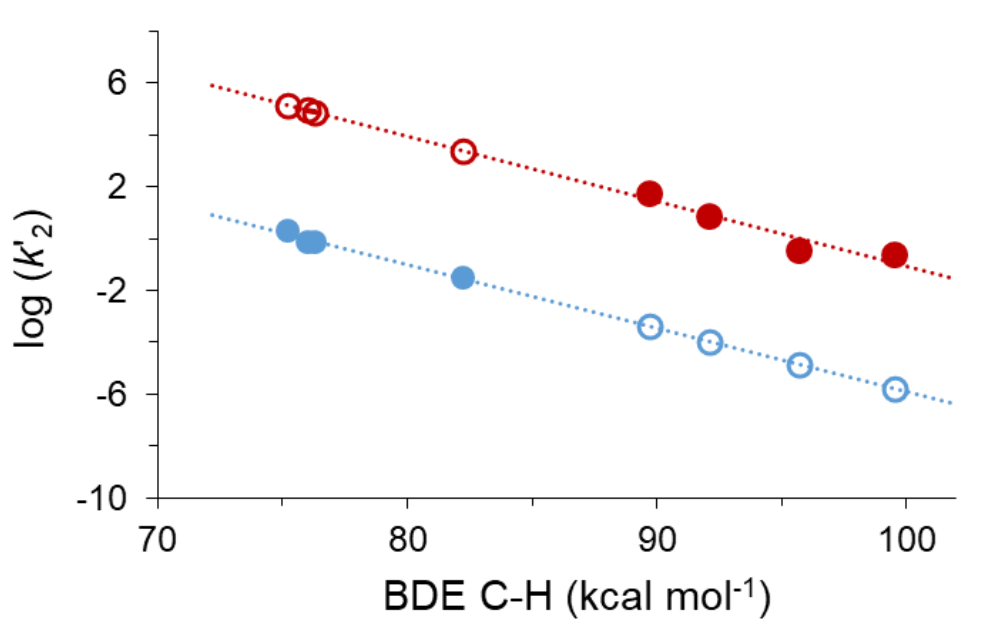

Figure 6. Correlation of $\log \left(k_{2}{ }^{\prime}\right)$ with the BDE of different substrates at $-40^{\circ} \mathrm{C}$ for $\mathbf{2} \mathbf{b}$ (blue line) and $\mathbf{3}$ (red line). Filled circles correspond to experimentally determined data and empty circles correspond to extrapolated values. The extrapolation made for compound $\mathbf{3}$ should be taken with a caveat, since a loss of linearity is likely to occur at BDE values below $90 \mathrm{kcal} \cdot \mathrm{mol}^{-1}$, as previously reported for other highly reactive HAT reagents (see text for more details).

Table 3. Experimental and extrapolated $k_{2}^{\prime}$ values for $\mathbf{2 b}$ and $\mathbf{3}$ (extrapolated values are shown in italics) at $40 \stackrel{\circ}{\circ}$.

\begin{tabular}{cccc}
\hline substrate & $\begin{array}{c}\mathrm{BDE} \\
\left(\mathrm{kcal} \mathrm{mol}^{-1}\right)\end{array}$ & $\begin{array}{c}\text { Compound 2b } \\
\mathrm{k}^{\prime}(\mathbf{2 b})\left(\mathrm{M}^{-1} \mathrm{~s}^{-1}\right)\end{array}$ & $\begin{array}{c}\text { Compound 3 } \\
\mathrm{k}^{\prime}(\mathbf{3})\left(\mathrm{M}^{-1} \mathrm{~s}^{-1}\right)\end{array}$ \\
\hline xanthene & 75.2 & $2.1 \pm 0.2$ & $1.4 \times 10^{5}$ \\
cyclohexadiene & 76.0 & $0.70 \pm 0.05$ & $8.7 \times 10^{4}$ \\
9,10-dihydroanthracene & 76.3 & $0.77 \pm 0.05$ & $7.4 \times 10^{4}$ \\
fluorene & 82.2 & $0.030 \pm 0.004$ & $2.5 \times 10^{3}$ \\
toluene & 89.7 & $4.2 \times 10^{-4}$ & $55 \pm 1^{\mathrm{a}}$ \\
tetrahydrofuran & 92.1 & $1.0 \times 10^{-4}$ & $7.2 \pm 0.2^{\mathrm{a}}$ \\
cyclooctane & 95.7 & $1.4 \times 10^{-5}$ & $0.34 \pm 0.01^{\mathrm{a}}$ \\
cyclohexane & 99.5 & $1.7 \times 10^{-6}$ & $0.23 \pm 0.01^{\mathrm{a}}$ \\
\hline a Reference 22. & & &
\end{tabular}


The KIE's determined for $\mathbf{2} \mathbf{b}$ and $\mathbf{3}$ are also significantly different. $\mathbf{2} \mathbf{b}$ exhibits very large KIE's ( 28), in agreement with the large values observed for synthetic and enzymatic oxoiron(IV) species, which are commonly rationalized on the basis of large tunneling contributions. ${ }^{15,50,62,63}$ In contrast, KIE's determined for $\mathbf{3}$ of $\sim 5-6$ are significantly smaller than those determined for $\mathbf{2 b}$, so they can still be accommodated by a classical treatment of the $\mathrm{C}-\mathrm{H}$ cleavage. Notably, these "classical" values resemble those obtained for catalytic $\mathrm{C}-\mathrm{H}$ oxidation systems with bio-inspired iron catalysts. ${ }^{64}$

Activation parameters in representative HAT reactions performed by $\mathbf{2 b}$ and $\mathbf{3}$ are collected in Table 4 . Activation entropies are large and negative, consistent with a bimolecular process, and those determined for $\mathbf{2} \mathbf{b}$ are systematically more negative. This pattern reflects a later and more ordered transition state for the less reactive $\mathbf{2 b}$. This provides some clues about the origin of the differences in the magnitude of the KIE's; tunneling contributions require close proximity between the hydrogen-donor and the hydrogen-acceptor and activation parameters indeed provide evidence for the necessary closer contact between the oxoiron(IV) (2b) and the substrate $\mathrm{C}-\mathrm{H}$ bond with respect to the same situation in the more reactive oxoiron(V) (3).

Table 4. Activation parameters for the reactions of $\mathbf{2 b}$ and $\mathbf{3}$ with $\mathrm{C}-\mathrm{H}$ bonds.

\begin{tabular}{cccccc}
\hline compound & substrate & $\begin{array}{c}\mathrm{BDE} \\
\left(\mathrm{kcal} \mathrm{mol}^{-1}\right)\end{array}$ & $\begin{array}{c}\Delta \mathrm{H}^{\neq} \\
\left(\mathrm{kcal} \mathrm{mol}^{-1}\right)\end{array}$ & $\begin{array}{c}\Delta \mathrm{S}^{\neq} \\
\left(\mathrm{cal} \mathrm{K}^{-1} \mathrm{~mol}^{-1}\right)\end{array}$ & ref \\
\hline $\mathbf{2 b}$ & xanthene & 75.2 & $6.4 \pm 0.6$ & $-27.2 \pm 2.6$ & this work \\
& cyclohexadiene & 76.0 & $7.3 \pm 0.5$ & $-25.6 \pm 2.1$ & this work \\
\hline \multirow{2}{*}{3} & toluene & 89.7 & $6.5 \pm 0.2$ & $-19.6 \pm 1.2$ & 22 \\
& cyclohexane & 99.5 & $8.8 \pm 0.7$ & $-18.2 \pm 1.9$ & 22 \\
\hline
\end{tabular}

The linear free energy correlation between $\log k_{2}^{\prime}$ and differences in enthalpy observed for the present system (Figure 6) provides interesting insights into the origin of the fast HAT reactivity of $\mathbf{3}$. With few exceptions, ${ }^{57,58,65}$ such a correlation is commonly observed for HAT reactions as described by the Bell-Evans-Polyani model. ${ }^{66}$ The enthalpy change of the present reactions corresponds to the difference between the energy that is required to break the $\mathrm{C}-\mathrm{H}$ bond $\left(\mathrm{BDE}_{\mathrm{C}-\mathrm{H}}\right)$ and the energy provided by the formation of the $\mathrm{FeO}-\mathrm{H}$ bond (BDEFeO-H) (eq. 2). Considering that cyclohexadiene reacts with $\mathbf{2 b}$ at a reaction rate $\left(k_{2}{ }^{\prime}=0.70 \mathrm{M}^{-1} \mathrm{~s}^{-1}\right)$ that is only 2.05 times the rate of reaction of 3 with cyclooctane $\left(k_{2}{ }^{\prime}=0.34 \mathrm{M}^{-1} \mathrm{~s}^{-1}\right)$, we can estimate that both reactions have similar activation free energies given the observed Bell-Evans-Polyani correlation (Figure 6). Therefore, the 20 $\mathrm{kcal} \cdot \mathrm{mol}^{-1}$ difference in $\mathrm{BDE}_{\mathrm{C}-\mathrm{H}}$ between these two substrates $\left(76.0 \mathrm{kcal} \cdot \mathrm{mol}^{-1}\right.$ for cyclohexadiene and 95.7 
$\mathrm{kcal} \cdot \mathrm{mol}^{-1}$ for cyclooctane) should approximately correspond to the difference in energy between the BDE of FellIO-H and Felv O-H.

$$
\begin{aligned}
& \mathrm{Fe}^{\mathrm{n}}=\mathrm{O}+\mathrm{C}-\mathrm{H} \underset{\text { reaction }}{\stackrel{\mathrm{HAT}}{\longrightarrow}} \mathrm{Fe}^{\mathrm{n}-1}-\mathrm{O}-\mathrm{H}+\mathrm{C} \cdot \\
& \Delta H^{O}=H_{\mathrm{FeO}-\mathrm{H}}^{O}-H_{\mathrm{FeO}}^{O}+H_{C \cdot}^{O}-H_{C-H}^{O} \\
& \Delta H^{O}=B D E_{C-H}-B D E_{F e O-H}
\end{aligned}
$$

BDE's for nonheme Fe ${ }^{\text {IIIO}} \mathrm{O}-\mathrm{H}$ complexes with neutral $\mathrm{N}$-rich ligands have been estimated to be between 78 $87 \mathrm{kcal} \cdot \mathrm{mol}^{-1}, 67,68$ and therefore, the BDE for the $\mathrm{Fe}^{\mathrm{IV} O}-\mathrm{H}$ should be around $100 \mathrm{kcal} \cdot \mathrm{mol}^{-1}$. This number falls between the $103 \mathrm{kcal} \cdot \mathrm{mol}^{-1}$ value estimated for the heme-thiolate peroxygenase $\mathrm{Cpd} \mathrm{I} 27$ and the $95 \mathrm{kcal} \cdot \mathrm{mol}^{-1}$ value recently determined by a combination of experimental and theoretical methods in horseradish peroxidase and in an aromatic peroxidase as reported by Green and coworkers. ${ }^{69}$ The Fe ${ }^{\mathrm{IV}} \mathrm{O}-\mathrm{H}$ value estimated for the present non-heme system constitutes one of the strongest described so far, attesting for the extraordinarily high HAT reactivity of 3. Remarkably, this estimation of the BDE for the Felv $\mathrm{O}-\mathrm{H}$ bond is in line with the value that we previously estimated on the basis of the reactivity of 3 towards toluene (estimated BDEO-H $=101$ $\left.\mathrm{kcal} \cdot \mathrm{mol}^{-1}\right) \cdot 22$ Interestingly, the $\sim 20 \mathrm{kcal} \cdot \mathrm{mol}^{-1}$ difference in FeO-H strength between $\mathbf{2} \mathbf{b}$ and $\mathbf{3}$ parallels the

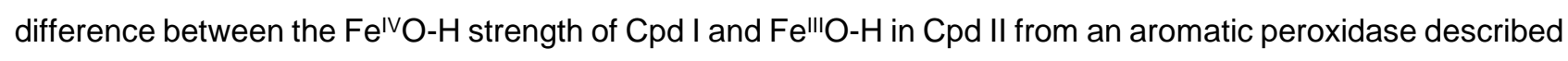
by Groves. ${ }^{27}$ Instead, Green has deduced a reduced impact of oxidation state in FeO-H bond dissociation energies in a P450 mutant (CYP158) by a combination of red-ox titrations and theoretical methods; values of

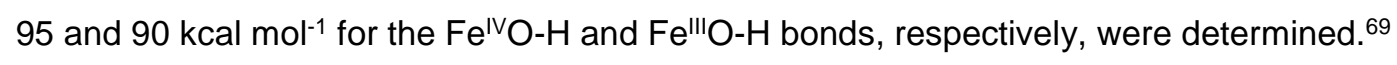

The different nature of the sixth ligand in $\mathbf{2} \mathbf{b}\left(\mathrm{CH}_{3} \mathrm{CN}\right)$ and $\mathbf{3}$ (carboxylate anion) deserves some comment. Acetonitrile is a neutral, $\pi$-acceptor ligand and stabilizes low oxidation states. On the other hand, acetate is an anionic sigma donor ligand that should favor higher oxidation states. Therefore, the extraordinarily higher reactivity of $\mathbf{3}$ when compared with $\mathbf{2} \mathbf{b}$ is likely to be even tamed by the different ligand. In other words, if the two complexes would share exactly the same ligand set, differences in reaction rates are expected to be even larger.

It is also remarkable that the hydrogen-atom abstraction reactions carried out by $\mathbf{2}$ and $\mathbf{3}$ entail changes in the spin state along the reaction. HAT reactions from 3 (which has a $S=1 / 2$ ground state) form an iron(IV)-hydroxo species, which possesses a $S=1$ or $S=2$ spin state, together with an alkyl radical. After the hydroxyl ligand rebound, an iron(III) complex with a $S=5 / 2$ is formed concomitantly with the hydroxylated product. Thus, a 
change in the spin state occurs along this reaction path. Indeed, we and others have investigated the spin state changes along the reaction of oxoiron $(\mathrm{V})$ with alkanes by computational methods ${ }^{70,71}$ and disclosed that reactions usually occur at the $S=1 / 2$ or $S=3 / 2$ surfaces, depending on which of the two spin states has the lower energy barriers. In some instances, a spin crossover before reaching the first transition state is necessary to access the most energetically favored path. The $S=5 / 2$ reaction path is usually much higher in energy with larger kinetic barriers. However, this is the most stable spin state for the reaction products, so that a spin crossover is necessary after the ligand rebound. A similar situation occurs with the HAT reactions carried out by oxoiron(IV) species analogous to 2 . In this case, most frequently reaction takes place at the quintuplet spin state $\left(S=2\right.$ ) even though the most stable spin configuration of the oxoiron(IV) is the triplet $(S=1) \cdot{ }^{72,73}$ (for a notable exception see ref. ${ }^{52}$ ) Thus, a spin crossover occurs before the transition state. In spite of the fact that spin-state changes are involved along the course of the reaction, spin-orbit couplings and spin-spin interactions remove the associated forbiddeness. Thus, the feasibility of the HAT reactions carried out by oxoiron(IV) and oxoiron(V) species appears to be dictated by ground state thermodynamics rather than by multiple state reactivities.

Differences in chemoselectivity between $\mathbf{2 b}$ and $\mathbf{3}$. The oxidation of cyclohexene constitutes a very informative mechanistic probe. Indeed, cyclohexene has been used as a substrate probe to study the reaction mechanism of oxidation reactions in enzymes and model systems. ${ }^{74,75}$ This molecule provides the oxidant with two possible channels of reactivity: abstraction of an allylic $\mathrm{C}-\mathrm{H}$ bond and $\mathrm{OAT}$ to the $\mathrm{C}=\mathrm{C}$ bond. Analysis of the oxidized products formed upon reaction of $\mathbf{2 b}$ or $\mathbf{3}$ with 100 equiv cyclohexene at $-40{ }^{\circ} \mathrm{C}$ in $\mathrm{CH}_{3} \mathrm{CN}$ showed completely different outcomes (Scheme 3). Under aerobic conditions, the oxoiron(IV) complex $\mathbf{2 b}$ afforded mainly allylic oxidation ( $31 \%$ yield of allylic ketone and $5 \%$ yield of allylic alcohol with traces of epoxide), while the oxoiron(V) compound 3 afforded mainly cyclohexene oxide $(60 \%$ yield) with minor amounts of allylic products ( $6 \%$ combined yield of allylic alcohol and ketone products). This comparison clearly indicates that $\mathbf{2 b}$ is a sluggish OAT reagent towards olefins, as previously observed for other oxoiron(IV) species, ${ }^{75}$ and instead favors one-electron processes, such as hydrogen atom abstraction at the allylic position. In contrast, $\mathbf{3}$ is an excellent two-electron oxidant, epoxidizing $\mathrm{C}=\mathrm{C}$ bonds instead of abstracting $\mathrm{H}$-atoms. 


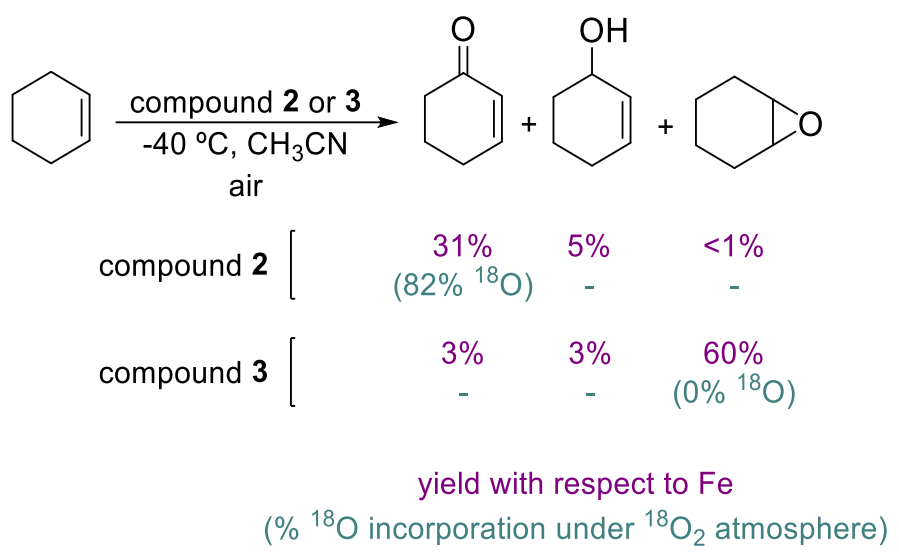

Scheme 3. Product distribution in the reaction of $\mathbf{2 b}$ and $\mathbf{3}$ with cyclohexene at $-40{ }^{\circ} \mathrm{C}$ in $\mathrm{CH}_{3} \mathrm{CN}$ under aerobic conditions.

Interestingly, when these reactions were carried out under a ${ }^{18} \mathrm{O}_{2}$ atmosphere the allylic ketone product derived from the reaction of $\mathbf{2 b}$ with cyclohexene incorporated $82 \%{ }^{18} \mathrm{O}$ (Figure S25), which indicates that after hydrogen atom abstraction by $\mathbf{2} \mathbf{b}$ the newly formed alkyl radical does not undergo rapid rebound and has a long enough lifetime to interact with gaseous dioxygen (Scheme 4). In contrast, no isotope labeling into the epoxide was detected in the same experiment carried out by 3 (Figure S25), which agrees with a direct OAT from the oxoiron $(\mathrm{V})$ to the $\mathrm{C}=\mathrm{C}$ bond. Of note, cyclohexene oxidation by $\mathbf{2} \mathbf{b}$ under a $\mathrm{N}_{2}$ atmosphere afforded the allylic alcohol as the major product ( $28 \%$ yield), while the production of allylic ketone was minimal ( $5 \%$ yield), which contrasts with the preferential formation of ketone in the presence of $\mathrm{O}_{2}$. Finally, control experiments in the presence of triphenylphosphine have been done to exclude the formation of hydroperoxides under the different conditions tested (see Experimental section). ${ }^{76}$

Differences in the lifetime of the carbon-centered radicals between $2 \mathbf{b}$ and 3 . The outcome in the oxidation of cyclohexene with $\mathbf{2} \mathbf{b}$ performed under ${ }^{18} \mathrm{O}_{2}$ atmosphere indicates that the hydroxyl ligand formed after HAT inefficiently rebounds with the newly formed carbon-centered radical, which diffuses out of the solvent cage, producing long-lived carbon-centered radicals that can interact with dioxygen, to give rise to the observed ${ }^{18} \mathrm{O}$-labelling of the allylic ketone (Scheme 4). In striking contrast, 3 hydroxylates alkanes with stereoretention, as demonstrated by the hydroxylation of the tertiary $\mathrm{C}-\mathrm{H}$ bonds of cis-1,2dimethylcyclohexane by 3 , which occurs with $96 \%$ stereoretention. ${ }^{22}$ This result excludes the formation of longlived carbon-centered radicals and indicates that the formed alkyl radicals after HAT rapidly recombine with the hydroxyl bound to the iron(IV) with no time for stereoscrambling. To further demonstrate this idea, we have carried out the oxidation of cyclohexane with 3 under a ${ }^{18} \mathrm{O}_{2}$ atmosphere, which mainly affords cyclohexanol. ${ }^{22}$ Conversely to what was observed in the oxidation of cyclohexene by $\mathbf{2 b}$, analysis of the cyclohexanol product 
showed no ${ }^{18} \mathrm{O}$ incorporation (Figure S26), further supporting the idea that the organic radicals formed along the reaction are very short-lived and do not have time to escape from the solvent cage and interact with atmospheric dioxygen.

Overall, the comparison between $\mathbf{2} \mathbf{b}$ and $\mathbf{3}$ constitutes a unique case in nonheme systems providing convincing evidence that the lifetime of the carbon-centered radical formed after the initial hydrogen-atom transfer (HAT) is dependent on the oxidation state of the iron center (Scheme 4). The data indicates that the putative hydroxoiron(IV) intermediate, formed after initial HAT by the oxoiron(V) species 3, can rapidly transfer the hydroxyl ligand (oxygen rebound) to the carbon-centered radical at reaction rates that exceed diffusion rates $\left(10^{9} \mathrm{~s}^{-1}\right)$. This observation is in line with the short lifetime of carbon-centered radicals formed by the heme enzyme cytochrome P450 (rate $\sim 10^{10}$ to $10^{11} \mathrm{~s}^{-1}$ ). ${ }^{77}$ On the other hand, the reaction of the hydroxoiron(III) species, formed after HAT by the oxoiron(IV) species $\mathbf{2 b}$, with the carbon-centered radical is slower than diffusion out of the reaction pocket, so that the latter process dominates the outcome. Again, this observation finds wide precedent in previous studies on the $\mathrm{C}-\mathrm{H}$ oxidation activity of nonheme oxoiron complexes ${ }^{78}$ and in more recent reports in which the rebound rates of ferric-methoxide and ferric-hydroxide complexes with carbon-centered radicals have been directly measured. ${ }^{79,80}$ The origin of this dichotomy may be tentatively traced to the redox nature of the rebound step, which entails a one-electron reduction of the iron center.

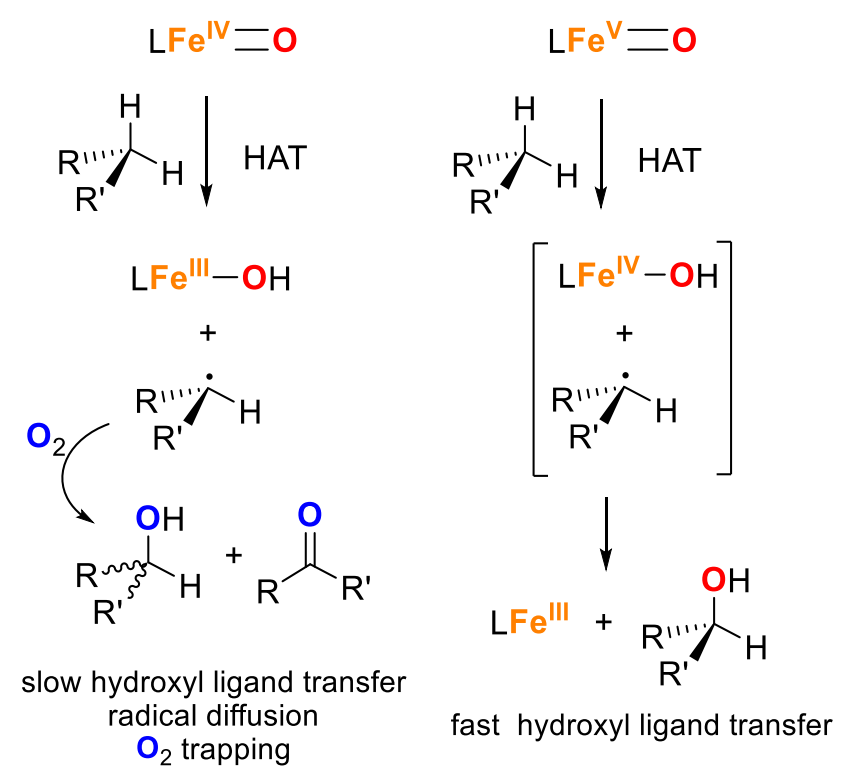

Scheme 4. Hydrogen atom transfer from C-H bonds by oxoiron(IV) and oxoiron(IV) species. 


\section{Conclusions}

In this work we have described the synthesis and characterization of an oxoiron(IV) species with a neutral tetradentate $\mathrm{N}$-based ligand, $\left[\mathrm{Fe}^{\mathrm{IV}}(\mathrm{O})\left(\mathrm{PyNMe}_{3}\right)\left(\mathrm{CH}_{3} \mathrm{CN}\right)\right]^{2+}$, that according to our spectroscopic studies exists as a mixture of two isomers (2a and $\mathbf{2} \mathbf{b})$. The reactivity of the thermodynamically more stable isomer $(\mathbf{2} \mathbf{b})$ towards $\mathrm{C}-\mathrm{H}$ bonds has been directly compared to that exhibited by the previously reported $1 \mathrm{e}^{-}$oxidized species $\left[\mathrm{Fe}^{\mathrm{V}}(\mathrm{O})(\mathrm{OAc})\left(\mathrm{PyNM}_{3}\right)\right]^{2+}(\mathbf{3}) .{ }^{22}$ Our data show that the oxoiron(IV) species $\mathbf{2} \mathbf{b}$ is four to five orders of magnitude slower than $\mathbf{3}$ in hydrogen atom abstraction reactions from $\mathrm{C}-\mathrm{H}$ bonds. Analysis of the collected kinetic data indicates that the origin of this huge difference lies in the strength of the $\mathrm{O}-\mathrm{H}$ bond formed after hydrogen-atom abstraction by the oxoiron unit and we estimate that the $\mathrm{O}-\mathrm{H}$ bond formed upon reaction of 3 with a $\mathrm{C}-\mathrm{H}$ bond is about $20 \mathrm{kcal} \cdot \mathrm{mol}^{-1}$ stonger than that derived from $\mathbf{2 b}$. On the basis of literature reports on the energy of the Fe ${ }^{\mathrm{III}} \mathrm{O}-\mathrm{H}$ bond of similar complexes, we estimate that the value of the $\mathrm{Fe}^{\mathrm{IV}} \mathrm{O}-\mathrm{H}$ bond derived from 3 is around $100 \mathrm{kcal} \cdot \mathrm{mol}^{-1}$, which is close to the reported values for highly active synthetic models of compound I of cytochrome P450. Overall, we have made a direct comparison between the oxidizing abilities of two non-heme oxoiron species with relevance in synthetic catalytic oxidation reactions and we have established that the strength of the $\mathrm{O}-\mathrm{H}$ bond formed after hydrogen atom abstraction is the key factor that determines their dramatic difference in HAT reactivity. In addition, our comparative study provides direct experimental evidence that the outcome of the carbon centered radical that forms after the initial HAT by the high valent oxo-iron complex is sensitive to the oxidation state of the complex. While 3 generates caged, shortlived radicals, 2 generates carbon-centered radicals that freely diffuse in solution. The most obvious consequence is that only 3 engages in stereoretentive hydroxylation reactions. Thus, the oxidation state of the iron center not only modulates the rate of HAT but also the rate of ligand rebound.

\section{Experimental section}

Materials. Reagents and solvents used were of commercially available reagent quality unless otherwise stated. Solvents were purchased from Scharlab, Acros or Sigma-Aldrich and used without further purification. Preparation and handling of air-sensitive materials were carried out in an $\mathrm{N}_{2}$ drybox (Jacomex) with $\mathrm{O}_{2}$ and $\mathrm{H}_{2} \mathrm{O}$ concentrations <1 ppm. PyNMe 3 , $\left.\left[\mathrm{Fe}^{\prime \prime}\left(\mathrm{CF}_{3} \mathrm{SO}_{3}\right)_{2}(\mathrm{PyNM})_{3}\right)\right]\left(\mathbf{1} \cdot \mathbf{C F}_{3} \mathbf{S O}_{3}\right)$ and $\mathbf{3}$ were prepared following previously described procedures. ${ }^{22,81}\left[\mathrm{Fe}^{\prime \prime}\left(\mathrm{PyNM}_{3}\right)\left(\mathrm{CH}_{3} \mathrm{CN}\right)_{2}\right]^{2+}(\mathbf{1})$ is obtained by exchange of the $\mathrm{CF}_{3} \mathrm{SO}_{3}$ anions by $\mathrm{CH}_{3} \mathrm{CN}$ upon dissolving $\mathbf{1}^{-} \mathrm{CF}_{3} \mathrm{SO}_{3}$ in this solvent. Xanthene-d $\mathrm{d}_{2}(>99 \% \mathrm{D}$ enrichment) and $9,10-$ dihydroanthracene- $\mathrm{d}_{4}$ (98\% $\mathrm{D}$ enrichment) were prepared according to literature protocols. ${ }^{82,83}$

Physical methods. UV-vis absorption spectroscopy was performed with an Agilent 50 Scan (Varian) UV-vis spectrophotometer with $1 \mathrm{~cm}$ quartz cells. Low temperature control was achieved with a cryostat from Unisoku 
Scientific Instruments, Japan. GC product analyses were performed on an Agilent 7820A gas chromatograph equipped with a HP-5 capillary column $30 \mathrm{~m} \times 0.32 \mathrm{~mm} \times 0.25 \mathrm{~mm}$ and a flame ionization detector. GC-MS analyses were performed on an Agilent $7890 \mathrm{~A}$ gas chromatograph equipped with an HP-5 capillary column interfaced with an Agilent 5975C mass spectrometer. For electron ionization (EI) the source was set at $70 \mathrm{eV}$, while a 50/50 NH $3: \mathrm{CH}_{4}$ mix was used as the ionization gas for chemical ionization (Cl) analyses. High resolution mass spectra (HR-MS) were recorded on a Bruker MicrOTOF-Q IITM instrument using ESI or Cryospray ionization sources at Serveis Tècnics of the University of Girona. Samples were introduced into the mass spectrometer ion source by direct infusion using a syringe pump and were externally calibrated using sodium triflate. The instrument was operated in positive ion mode.

Fe K-edge $\mathrm{X}$-ray absorption spectra on the frozen solution of $\mathbf{2 a}$ and $\mathbf{2 b}$ were collected at $10 \mathrm{~K}$ in the energy range 6900 to $8000 \mathrm{eV}$ on beamline 9-3 of the Stanford Synchrotron Radiation Lightsource (SSRL) of SLAC National Accelerator Laboratory. A 100-element solid-state Ge detectors (Canberra) were used to obtain the XAS data. An iron foil was used for the energy calibration of the beam and the first inflection point of the edge was assigned to $7112.0 \mathrm{eV}$. Seven scans of the fluorescence mode XAS spectra were collected on $\mathbf{2 a}$ and $\mathbf{2 b}$. To increase the signal-to-noise ratio of the spectra, a $6-\mu \mathrm{m}$ Mn filter along with the Soller slit was placed in between detector and the sample. Data reduction, averaging, and normalization were performed using the program EXAFSPAK. ${ }^{84}$ The pre-edge features were fitted using the Fityk software ${ }^{85}$ with pseudo-Voigt functions composed of 50:50 Gaussian/Lorentzian functions.

Resonance Raman spectra were obtained on frozen samples of $\mathbf{2 a}$ and $\mathbf{2 b}$ at $77 \mathrm{~K}$ with excitation at $457 \mathrm{~nm}$ laser (50 $\mathrm{mW}$ at source, Cobolt Lasers) through the sample in an NMR tube using a $135^{\circ}$ scattering arrangement (parallel to the slit direction). The collimated Raman scattering was collected using two Plano convex lenses ( $f=10 \mathrm{~cm}$, placed at an appropriate distance) through appropriate long pass edge filters (Semrock) into an Acton AM-506M3 monochromator equipped with a Princeton Instruments ACTON PyLON LN/CCD-1340x400 detector. The detector was cooled to $-120^{\circ} \mathrm{C}$ prior to the experiments. Spectral calibration was performed using the Raman spectrum of acetonitrile/toluene 50:50 (v:v). ${ }^{86}$ Each spectrum was accumulated, typically 60 times with $5 \mathrm{~s}$ acquisition time, resulting in a total acquisition time of 5 min per spectrum. The collected data was processed using Spectragryph, ${ }^{87}$ and a multi-point baseline correction was performed for all spectra.

NMR spectra were recorded on a Bruker Avance III HD nanobay $400 \mathrm{MHz}$ spectrometer or on a Bruker Ultrashield Avance III400. Temperatures for low temperature experiments were determined by calibration using a solution of methanol and TMS as the standard. $0.5 \mathrm{~mL} \mathrm{4-mM} \mathrm{solution} \mathrm{of} 1$ was prepared for NMR experiments and the corresponding oxoiron(IV) samples were prepared by adding 1.1 equiv $\mathrm{BBNIO}_{4}$ and 1 equiv $\mathrm{HClO}_{4}$ to this solution in an NMR tube at $253 \mathrm{~K}$.

Mössbauer spectra were recorded with two spectrometers using Janis Research (Wilmington, MA) SuperVaritempdewars that allow studies in applied magnetic fields up to $7.5 \mathrm{~T}$ in the temperature range from 1.5 to $200 \mathrm{~K}$. Mössbauer spectral simulations were performed using the WMOSS software package (SEE Co, Edina,MN). The figures of Mössbauer spectra were plotted in SpinCount (provided by Prof. M. P. Hendrich of Carnegie Mellon University).

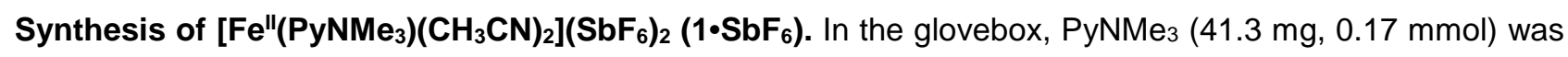
dissolved in $\mathrm{CH}_{3} \mathrm{CN}(2 \mathrm{~mL})$. Afterwards $\mathrm{FeCl}_{2}(21.1 \mathrm{mg}, 0.17 \mathrm{mmol})$ was added directly as a solid and the 
mixture was stirred for 24 hours. A color change from pale yellow to deep orange was observed. Then, AgSbF 6 (121 mg, $0.34 \mathrm{mmol}$ ) was added, which caused the immediate formation of a white precipitate corresponding to $\mathrm{AgCl}$ and the solution turned dark green. After stirring for $2 \mathrm{~h}$ the solution was filtered over Celite ${ }^{\circledR}$ to remove precipitated $\mathrm{AgCl}$. Then, direct addition of diethyl ether $(10 \mathrm{~mL})$ caused the precipitation of the complex which was separated and dried. Finally, the resulting solid was dissolved using a mixture of $\mathrm{CH}_{2} \mathrm{Cl}_{2}(1.5 \mathrm{~mL})$ and $\mathrm{CH}_{3} \mathrm{CN}(0.5 \mathrm{~mL})$. Slow diethyl ether diffusion over the resulting solution in the anaerobic box afforded $41.8 \mathrm{mg}$ ( $0.05 \mathrm{mmol}, 32 \%$ yield) of dark brown crystals corresponding to $\mathbf{1} \cdot \mathbf{S b F}_{\mathbf{6}}$ suitable for X-ray diffraction (see $\mathrm{SI}$ ). ${ }^{1} \mathrm{H}-\mathrm{NMR}\left(\mathrm{CD}_{3} \mathrm{CN}, 400 \mathrm{MHz}, 298 \mathrm{~K}\right) \delta$, ppm: 114, 99, 87, 77, 66, 56, 55, 12, -24, -35. ESI-QTOF-MS (m/z): calcd for $\left[\mathrm{Fe}\left(\mathrm{PyNMe}_{3}\right)\left(\mathrm{CH}_{3} \mathrm{CN}\right)\right]^{2+172.5802}$ found 172.5806; calcd for [ $\left.\left.\mathrm{Fe}\left(\mathrm{PyNMe}_{3}\right)\right]\left(\mathrm{SbF}_{6}\right)\right]^{+} 539.0287$ found 539.0290. Anal. Calcd for $\mathrm{C}_{18} \mathrm{H}_{30} \mathrm{~F}_{12} \mathrm{FeN}_{6} \mathrm{Sb}_{2}$ : C, 25.20; H, 3.53; N: 9.80. Found: C, 25.18; H, 3.21; N, 9.72.

Synthesis of $\mathbf{d}_{4}-\mathrm{PyNMe}_{3} . \mathrm{PyNMe}_{3}(96.6 \mathrm{mg}, 0.39 \mathrm{mmol})$ and $\mathrm{NaH}(39.3 \mathrm{mg}, 1.56 \mathrm{mmol})$ were suspended in $\mathrm{CD}_{3} \mathrm{CN}(2.5 \mathrm{~mL})$ in a two-necked round flask inside the glovebox. The mixture was taken out the glovebox and stirred at $50 \stackrel{\circ}{\circ}$ under an inert atmosphere for 24 hours. Then $\mathrm{D}_{2} \mathrm{O}(2 \mathrm{~mL})$ was added to quench the reaction. Upon removal of $\mathrm{CD}_{3} \mathrm{CN}$ under vacuum, the residue was extracted with $\mathrm{CH}_{2} \mathrm{Cl}_{2}(4 \times 10 \mathrm{~mL})$ and the organic layer was dried with $\mathrm{MgSO}_{4}$ and filtered. The solvent was removed under reduced pressure obtaining a brown oil. The product was further purified by column chromatography over silica using an initial mixture of $\mathrm{CH}_{2} \mathrm{Cl}_{2}: \mathrm{MeOH}: \mathrm{NH}_{3} 80: 20: 4$ and slowly raising the polarity to $60: 40: 4$ to ensure the complete elution of $\mathrm{d}_{4}-$ PyNMe $3.53 .2 \mathrm{mg}\left(0.21 \mathrm{mmols}, 54 \%\right.$ yield) of the pure deuterated ligand were obtained. ${ }^{1} \mathrm{H}-\mathrm{NMR}\left(\mathrm{CDCl}_{3}, 400\right.$ $\mathrm{MHz}, 298 \mathrm{~K}) \delta$, ppm: 7.58 (t, J= $7.7 \mathrm{~Hz}, 1 \mathrm{H}), 7.10$ (d, J= 7.7 Hz, 2H), 2.55-2.46 (m, 14H), 2.21 (s, 3H). ${ }^{13} \mathrm{C}-$ $\operatorname{NMR}\left(\mathrm{CDCl}_{3}, 100 \mathrm{MHz}, 298 \mathrm{~K}\right) \delta$, ppm: 157.4, 136.8, 122.2, $61.9(\mathrm{~m}), 53.1,52.4,45.1(2 \mathrm{C})$.

Synthesis of $\left[\mathrm{Fe}^{\prime \prime}\left(\mathrm{CF}_{3} \mathrm{SO}_{3}\right)_{2}\left(\mathrm{~d}_{4}-\mathrm{PyNMe}_{3}\right)\right]\left(\mathbf{d}_{4}-1 \cdot \mathrm{CF}_{3} \mathrm{SO}_{3}\right)$. [ $\left.\mathrm{Fe}^{\prime \prime}\left(\mathrm{CF}_{3} \mathrm{SO}_{3}\right)_{2}\left(\mathrm{CH}_{3} \mathrm{CN}\right)_{2}\right](91.9 \mathrm{mg}, 0.21 \mathrm{mmol})$ was added directly as a solid to a vigorously stirred solution of $\mathrm{d}_{4}-\mathrm{PyNMe}_{3}(53.2 \mathrm{mg}, 0.21 \mathrm{mmol})$ in tetrahydrofuran $(2 \mathrm{~mL})$. The solution turned from a pale color to an intense yellow color. The mixture was stirred overnight and then the obtained precipitate was separated, washed with tetrahydrofuran and dried under vacuum. Finally, the solid was redissolved in the minimum amount of $\mathrm{CH}_{2} \mathrm{Cl}_{2}$ and a few drops of acetonitrile were added to ensure the complete dissolution of the complex. After filtration over Celite $\AA$, slow diethyl ether diffusion over the resulting solution afforded $63.9 \mathrm{mg}(0.11 \mathrm{mmol}, 52 \%)$ of yellow crystals. ${ }^{1} \mathrm{H}-\mathrm{NMR}\left(\mathrm{CD}_{3} \mathrm{CN}, 243 \mathrm{MHz}, 298\right.$ K) $\delta, p p m=44.8,34.1,24.5,18.7,10.5,-10.7$. ESI-QTOF-MS (m/z): calcd for $\left[\mathrm{Fe}\left(\mathrm{d}_{4}-\mathrm{PyNMe}_{3}\right)\left(\mathrm{OH}_{2}\right)\right]^{2+}$ 163.0848 found 163.0856 ; calcd for [Fe(d 4 -PyNMe 3$)](\mathrm{OTf})]^{+} 457.1116$ found 457.1125 .

Generation of 2 with $\mathrm{Bu}_{4} \mathrm{NIO}_{4}$ and TfOH. A $1 \mathrm{mM}$ solution of 1 in $\mathrm{CH}_{3} \mathrm{CN}$ (or in a 1:1 mixture of $\left.\mathrm{CH}_{3} \mathrm{CN}: \mathrm{CH}_{2} \mathrm{Cl}_{2}\right)$ was prepared into the glovebox. $2 \mathrm{~mL}$ of this solution $(2 \mu \mathrm{mol}$ of 1$)$ were introduced in a UVvis cuvette, that was capped with a septum, taken out from the glovebox, placed in the cryostat of the UV-vis spectrophotometer and cooled down to the set temperature $\left(-20{ }^{\circ} \mathrm{C},-40{ }^{\circ} \mathrm{C}\right.$ or $\left.-60{ }^{\circ} \mathrm{C}\right)$. Once the desired temperature was reached, an initial UV-vis absorption spectrum of 1 was recorded. Then $60 \mu \mathrm{L}$ of a solution containing 1.1 equiv $\mathrm{Bu}_{4} \mathrm{NIO}_{4}$ and 0.8 equiv $\mathrm{TfOH}$ in $\mathrm{CH}_{3} \mathrm{CN}$ were added in the cuvette. The formation of two bands at $\sim 800$ and $\sim 980 \mathrm{~nm}$ was immediately observed. When the generation of 2 was carried out at $-20 \stackrel{\circ}{ } \mathrm{C}$, the band at $\sim 980 \mathrm{~nm}(\mathbf{2 b})$ was the most intense. Conversely, at $-60^{\circ} \mathrm{C}$ the band at $\sim 800 \mathrm{~nm}$ was the highest in intensity (corresponding to a mixture of $\mathbf{2 a}$ and $\mathbf{2 b}$ ). Finally, at $-40{ }^{\circ} \mathrm{C}$ the band at $\sim 800 \mathrm{~nm}$ was the most 
intense right after addition of the oxidant (mixture of $\mathbf{2 a}$ and $\mathbf{2 b}$ ) but it decreased over time in favor of the one at $\sim 980 \mathrm{~nm}(\mathbf{2 b})$ that became the major one.

The oxoiron(IV) complexes $\mathbf{d}_{4} \mathbf{- 2} \mathbf{b}$ and $\mathbf{2} \cdot \mathbf{S b F}_{6}$ were generated following the above described method for the preparation of $\mathbf{2}$ but using $\mathbf{d}_{4}-\mathbf{1} \cdot \mathrm{CF}_{3} \mathrm{SO}_{3}$ or $\mathbf{1} \cdot \mathbf{S b F}_{6}$ as starting material.

Generation of 2 with 2-tBuSO${ }_{2}-\mathrm{C}_{6} \mathrm{H}_{4} \mathrm{IO}$. A $1 \mathrm{mM}$ solution of $\mathbf{1}$ in $\mathrm{CH}_{3} \mathrm{CN}$ was prepared into the glovebox. 2 $\mathrm{mL}$ of this solution ( $2 \mu \mathrm{mol}$ of $\mathbf{1}$ ) were introduced in a UV-vis cuvette, that was capped with a septum, taken out from the glovebox, placed in the cryostat of the UV-vis spectrophotometer and cooled down to $-40{ }^{\circ} \mathrm{C}$. Once the desired temperature was reached, an initial UV-vis absorption spectrum of 1 was recorded. Then $100 \mu \mathrm{L}$ of a solution containing 2- $\mathrm{BBSO}_{2}-\mathrm{C}_{6} \mathrm{H}_{4} \mathrm{IO}(2.2 \mu \mathrm{mol})$ in $\mathrm{CH}_{2} \mathrm{Cl}_{2}$ were added in the cuvette. As previously observed in the generation of 2 with 1.1 equiv $\mathrm{Bu}_{4} \mathrm{NIO}_{4}$ and 0.8 equiv $\mathrm{TfOH}$, the intensity of the band at $\sim 800$ $\mathrm{nm}$ decreased over time in favour of the one at $\sim 980 \mathrm{~nm}$, which became the most intense.

Reaction of 2 with substrates. For the reactivity studies, 2 was generated as described above using $\mathrm{Bu}_{4} \mathrm{NIO}_{4}$ and $\mathrm{TfOH}$.

Oxidation of $p$-X-thioanisole by $\mathbf{2 b}$ at $-40^{\circ} \mathrm{C}$. Once $\mathbf{2 b}$ was fully formed in $\mathrm{CH}_{3} \mathrm{CN}, 50$ or $100 \mu \mathrm{L}$ of a solution of the substrate in $\mathrm{CH}_{3} \mathrm{CN}$ containing the desired amount of substrate (10 - 100 equiv) were added. The characteristic absorption band at $990 \mathrm{~nm}$ of $\mathbf{2 b}$ decayed following a single exponential function from which kinetic data could be extracted. In the case of thioanisole, after total decay of the UV-vis absorption band of $\mathbf{2 b}$, biphenyl was added as internal standard and the reaction mixture was rapidly filtered through a silica plug, which was washed with ethyl acetate. This solution was then analyzed with GC to calculate the product yield. Oxidation of hydrocarbons by $\mathbf{2 b}$ at $-40 \stackrel{\circ}{\circ}$. Once $\mathbf{2 b}$ was fully formed in a $1: 1$ mixture of $\mathrm{CH}_{3} \mathrm{CN}: \mathrm{CH}_{2} \mathrm{Cl}_{2}$, between 100 and $250 \mu \mathrm{L}$ of a solution containing the desired amount of substrate (10 - 70 equiv) in a 1:1 mixture of $\mathrm{CH}_{3} \mathrm{CN}: \mathrm{CH}_{2} \mathrm{Cl}_{2}$ were added. The characteristic absorption band at $990 \mathrm{~nm}$ of $\mathbf{2} \mathbf{b}$ decayed following a single exponential function from which kinetic data could be extracted.

Oxidation of sulfides and hydrocarbons by $2 \mathrm{a}$ at $-60 \stackrel{\circ}{\circ} \mathrm{C}$ in a $1: 1$ mixture of $\mathrm{CH}_{3} \mathrm{CN}: \mathrm{CH}_{2} \underline{\mathrm{Cl}_{2}}$. To a solution of compound $\mathbf{2} \mathbf{a}+\mathbf{2} \mathbf{b}$, generated in a 1:1 mixture of $\mathrm{CH}_{3} \mathrm{CN}: \mathrm{CH}_{2} \mathrm{Cl}_{2}$ at $-60{ }^{\circ} \mathrm{C}$ (see above for more details), $100 \mu \mathrm{L}$ of a solution containing the desired amount of substrate (10 - 46 equiv) in a 1:1 mixture of $\mathrm{CH}_{3} \mathrm{CN}: \mathrm{CH}_{2} \mathrm{Cl}_{2}$ were added. Disappearance of the UV-vis absorption band at $792 \mathrm{~nm}$ was monitored upon substrate addition and the decay was fitted to a single exponential after subtraction of the contribution from $\mathbf{2 b}$ (see Supporting Information for more details)

Oxidation of sulfides and hydrocarbons with $\mathbf{2 b}$ at $-60{ }^{\circ} \mathrm{C}$ in a $1: 1$ mixture of $\mathrm{CH}_{3} \mathrm{CN}: \mathrm{CH}_{2} \mathrm{Cl}_{2}$. A solution of $\mathbf{2 b}$ was obtained at $-40{ }^{\circ} \mathrm{C}$ in a 1:1 mixture of $\mathrm{CH}_{3} \mathrm{CN}: \mathrm{CH}_{2} \mathrm{Cl}_{2}$ (see above for more details) after isomerisation of 2a. The solution of $\mathbf{2 b}$ was cooled down to $-60 \stackrel{\circ}{\circ}$ and $100 \mu \mathrm{L}$ of a solution containing the desired amount of substrate (10 - 46 equiv) in a $1: 1$ mixture of $\mathrm{CH}_{3} \mathrm{CN}: \mathrm{CH}_{2} \mathrm{Cl}_{2}$ were added. Disappearance of the UV-vis absorption band characteristic of $\mathbf{2} \mathbf{b}$ at $990 \mathrm{~nm}$ was monitored upon substrate addition and the decay was fitted to a single exponential function from which the reaction rate could be extracted.

Oxidation of cyclohexene with $\mathbf{2 b}$ and $\mathbf{3}$ at $-40 \stackrel{\circ}{\circ}$. Once $\mathbf{2 b}$ or $\mathbf{3}$ were fully formed in pure $\mathrm{CH}_{3} \mathrm{CN}, 200 \mu \mathrm{L}$ of a solution containing 100 equiv of cyclohexene in $\mathrm{CH}_{3} \mathrm{CN}$ were added. After total decay of the UV-vis absorption band of $\mathbf{2 b}$ at $990 \mathrm{~nm}$ or $\mathbf{3}$ at $490 \mathrm{~nm}$, biphenyl was added as internal standard and the reaction mixture was rapidly filtered through a silica plug and subsequentialy washed with ethyl acetate. At this point 
an aliquote of the solution was analyzed by GC and GC-MS. To the remaining solution, an excess of solid $\mathrm{PPh}_{3}$ was added and analyzed by GC to exclude the formation of hydroperoxides, as previously reported. ${ }^{76}$ This experiment was carried out under different atmoshperes, namely $\mathrm{N}_{2}$, air and ${ }^{18} \mathrm{O}_{2}$.

Oxidation of cyclohexane by 3 at $-40 \stackrel{\circ}{\circ}$. Once 3 was fully formed in $\mathrm{CH}_{3} \mathrm{CN}, 100 \mu \mathrm{L}$ of a solution containing 45 equiv of cyclohexane in $\mathrm{CH}_{3} \mathrm{CN}$ were added. After total decay of the UV-vis absorption band of 3 at 490 $\mathrm{nm}$, the reaction mixture was rapidly filtered through a silica plug and subsequentialy washed with ethyl acetate. At this point an aliquote of the solution was analyzed by GC and GC-MS. This experiment was carried out under $\mathrm{N}_{2}$ and ${ }^{18} \mathrm{O}_{2}$ atmoshperes.

Eyring plot for the reaction of $\mathbf{2} \mathbf{b}$ with cyclohexadiene and xanthene. Once $\mathbf{2} \mathbf{b}$ was fully formed in $\mathbf{a} 1: 1$ mixture of $\mathrm{CH}_{3} \mathrm{CN}: \mathrm{CH}_{2} \mathrm{Cl}_{2}, 100 \mu \mathrm{L}$ of a solution containing 10 equiv of cyclohexadiene or xanthene in a 1:1 mixture of $\mathrm{CH}_{3} \mathrm{CN}: \mathrm{CH}_{2} \mathrm{Cl}_{2}$ were added. The decay of the absorption band of $\mathbf{2 b}$ at $990 \mathrm{~nm}$ was monitored and fitted to a single exponential function from which the observed rate constant ( $\left.k_{\mathrm{obs}}\right)$ could be extracted. This experiment was repeated at five different temperatures $(233 \mathrm{~K}-273 \mathrm{~K})$ for each substrate, in order to calculate the activation parameters $\left(\Delta \mathrm{H}^{\neq}\right.$and $\left.\Delta \mathrm{S}^{\neq}\right)$by plotting the $\ln \left(k_{2} / \mathrm{T}\right)$ values as function of $1 / T$.

Supporting information. Characterization of $\mathbf{d}_{4}-\mathrm{PyNMe}_{3}, \mathrm{~d}_{4}-\mathbf{1} \cdot \mathrm{CF}_{3} \mathrm{SO}_{3}$ and $\mathbf{1} \cdot \mathrm{SbF}_{6}, \mathrm{XAS}$ analysis for $\mathbf{2 a}$ and $\mathbf{2 b}$, raw Mössbauer spectra for $\mathbf{2} \mathbf{a}$ and $\mathbf{2} \mathbf{b},{ }^{1} \mathrm{H}-\mathrm{NMR}$ characterization of $\mathbf{2} \mathbf{b}$ and $\mathbf{d}_{\mathbf{4}} \mathbf{- 2} \mathbf{b}$, UV-vis spectroscopy of the conversion of $\mathbf{2 a}$ to $\mathbf{2} \mathbf{b}$ and comparison of their reactivities in OAT and HAT processes, UV-vis spectroscopy of the reaction of $\mathbf{2} \mathbf{b}$ in OAT and HAT processes, MS spectra for the reactions of $\mathbf{2} \mathbf{b}$ and $\mathbf{3}$ with cyclohexene and cyclohexane, DFT calculations for the structure of $\mathbf{2 a}$ and $\mathbf{2} \mathbf{b}$ including predicted ${ }^{1} \mathrm{H}-\mathrm{NMR}$ chemical shifts and geometry coordinates. This material is available free of charge via the Internet at http://pubs.acs.org.

\section{Acknowledgements}

The work at the University de Girona was supported by by the Spanish Ministry of Science (CTQ2015-70795P to M.C., CTQ2016-77989-P to A.C.) and Generalitat de Catalunya (ICREA Academia Award to M.C. and 2014 SGR 862). The European Commission is acknowledged for financial support through the NoNoMeCat project (675020-MSCA-ITN-2015-ETN). The work at the University of Minnesota and Carnegie Mellon University was supported by the US National Science Foundation respectively through grants $\mathrm{CHE}-1665391$ to L.Q. and CHE-1654060 to Y.G.). XAS data were collected on Beamline 9-3 at the Stanford Synchrotron Radiation Light source, SLAC National Accelerator Laboratory. SLAC is supported by the U.S. Department of Energy (DOE), Office of Science, Office of Basic Energy Sciences under Contract No. DE-AC02-76SF00515. Use of Beamline 9-3 is supported by the DOE Office of Biological and Environmental Research and the National Institutes of Health, National Institute of General Medical Sciences (including P41GM103393). The Bruker Avance III HD nanobay $400 \mathrm{MHz}$ spectrometer used in this study was purchased from funds provided by the Office of the Vice President of Research, the College of Science and Engineering, and the Department of Chemistry at the University of Minnesota. We thank the Pittsburgh Supercomputing Center for granting us computational resources (CHE180020P to R.F. and Y.G.).

\section{References}

(1) Rittle, J.; Green, M. T. Cytochrome P450 Compound I: Capture, Characterization, and C-H Bond Activation Kinetics. Science 2010, 330, 933-937. 
(2) Huang, X.; Groves, J. T. Oxygen Activation and Radical Transformations in Heme Proteins and Metalloporphyrins. Chem. Rev. 2018, 118, 2491-2553.

(3) Ortiz de Montellano, P. R. Hydrocarbon Hydroxylation by Cytochrome P450 Enzymes. Chem. Rev. 2010, 110, 932-948.

(4) Shaik, S.; Cohen, S.; Wang, Y.; Chen, H.; Kumar, D.; Thiel, W. P450 Enzymes: Their Structure, Reactivity, and Selectivity-Modeled by QM/MM Calculations. Chem. Rev. 2010, 110, 949-1017.

(5) Perry, C.; de los Santos, Emmanuel L. C.; Alkhalaf, L. M.; Challis, G. L. Rieske non-heme irondependent oxygenases catalyse diverse reactions in natural product biosynthesis. Nat. Prod. Rep. 2018, 35, 622-632.

(6) Kovaleva, E. G.; Lipscomb, J. D. Versatility of biological non-heme Fe(II) centers in oxygen activation reactions. Nature Chem. Biol. 2008, 4, 186.

(7) Chakrabarty, S.; Austin, R. N.; Deng, D.; Groves, J. T.; Lipscomb, J. D. Radical Intermediates in Monooxygenase Reactions of Rieske Dioxygenases. J. Am. Chem. Soc. 2007, 129, 3514-3515.

(8) Krebs, C.; Galonić Fujimori, D.; Walsh, C. T.; Bollinger, J. M. Non-Heme Fe(IV)-Oxo Intermediates. Acc. Chem. Res. 2007, 40, 484-492.

(9) Price, J. C.; Barr, E. W.; Tirupati, B.; Bollinger, J. M.; Krebs, C. The First Direct Characterization of a High-Valent Iron Intermediate in the Reaction of an a-Ketoglutarate-Dependent Dioxygenase: A High-Spin $\mathrm{Fe}(\mathrm{IV})$ Complex in Taurine/a-Ketoglutarate Dioxygenase (TauD) from Escherichia coli. Biochemistry 2003, 42, 7497-7508.

(10) Hoffart, L. M.; Barr, E. W.; Guyer, R. B.; Bollinger, J. M.; Krebs, C. Direct spectroscopic detection of a $\mathrm{C}-\mathrm{H}$-cleaving high-spin $\mathrm{Fe}(\mathrm{IV})$ complex in a prolyl-4-hydroxylase. Proc. Natl. Acad. Sci. USA 2006, 103, 1473814743.

(11) Eser, B. E.; Barr, E. W.; Frantom, P. A.; Saleh, L.; Bollinger, J. M.; Krebs, C.; Fitzpatrick, P. F. Direct Spectroscopic Evidence for a High-Spin Fe(IV) Intermediate in Tyrosine Hydroxylase. J. Am. Chem. Soc. 2007, 129, 11334-11335.

(12) Panay, A. J.; Lee, M.; Krebs, C.; Bollinger, J. M.; Fitzpatrick, P. F. Evidence for a High-Spin Fe(IV) Species in the Catalytic Cycle of a Bacterial Phenylalanine Hydroxylase. Biochemistry 2011, 50, 1928-1933.

(13) Wong, S. D.; Srnec, M.; Matthews, M. L.; Liu, L. V.; Kwak, Y.; Park, K.; Bell lii, C. B.; Alp, E. E.; Zhao, J.; Yoda, Y.; Kitao, S.; Seto, M.; Krebs, C.; Bollinger, J. M.; Solomon, E. I. Elucidation of the $\mathrm{Fe}(\mathrm{IV})=\mathrm{O}$ intermediate in the catalytic cycle of the halogenase SyrB2. Nature 2013, 499, 320.

(14) Galonić Fujimori, D.; Barr, E. W.; Matthews, M. L.; Koch, G. M.; Yonce, J. R.; Walsh, C. T.; Bollinger, J. M.; Krebs, C.; Riggs-Gelasco, P. J. Spectroscopic Evidence for a High-Spin Br-Fe(IV)-Oxo Intermediate in the a-Ketoglutarate-Dependent Halogenase CytC3 from Streptomyces. J. Am. Chem. Soc. 2007, 129, 1340813409 .

(15) Galonić, D. P.; Barr, E. W.; Walsh, C. T.; Bollinger Jr, J. M.; Krebs, C. Two interconverting Fe(IV) intermediates in aliphatic chlorination by the halogenase CytC3. Nature Chem. Biol. 2007, 3, 113.

(16) McDonald, A. R.; Que, L. High-valent nonheme iron-oxo complexes: Synthesis, structure, and spectroscopy. Coord. Chem. Rev. 2013, 257, 414-428.

(17) Ray, K.; Pfaff, F. F.; Wang, B.; Nam, W. Status of Reactive Non-Heme Metal-Oxygen Intermediates in Chemical and Enzymatic Reactions. J. Am. Chem. Soc. 2014, 136, 13942-13958.

(18) Guo, M.; Corona, T.; Ray, K.; Nam, W. Heme and Nonheme High-Valent Iron and Manganese Oxo Cores in Biological and Abiological Oxidation Reactions. ACS Cent. Sci. 2019, 5, 13-28.

(19) Oloo, W. N.; Que, L. Bioinspired Nonheme Iron Catalysts for C-H and C=C Bond Oxidation: Insights into the Nature of the Metal-Based Oxidants. Acc. Chem. Res. 2015, 48, 2612-2621.

(20) Olivo, G.; Cussó, O.; Borrell, M.; Costas, M. Oxidation of alkane and alkene moieties with biologically inspired nonheme iron catalysts and hydrogen peroxide: from free radicals to stereoselective transformations. J. Biol. Inorg. Chem. 2017, 22, 425-452.

(21) Meyer, S.; Klawitter, I.; Demeshko, S.; Bill, E.; Meyer, F. A Tetracarbene-Oxoiron(IV) Complex. Angew. Chem. Int. Ed. 2013, 52, 901-905.

(22) Serrano-Plana, J.; Oloo, W. N.; Acosta-Rueda, L.; Meier, K. K.; Verdejo, B.; García-España, E.; Basallote, M. G.; Münck, E.; Que, L.; Company, A.; Costas, M. Trapping a Highly Reactive Nonheme Iron Intermediate That Oxygenates Strong C-H Bonds with Stereoretention. J. Am. Chem. Soc. 2015, 137, 1583315842.

(23) de Oliveira, F. T.; Chanda, A.; Banerjee, D.; Shan, X.; Mondal, S.; Que, L.; Bominaar, E. L.; Münck, E.; Collins, T. J. Chemical and Spectroscopic Evidence for an $\mathrm{Fe}^{\mathrm{V}}$-Oxo Complex. Science 2007, 315, 835-838. (24) Kwon, E.; Cho, K.-B.; Hong, S.; Nam, W. Mechanistic insight into the hydroxylation of alkanes by a nonheme iron(V)-oxo complex. Chem. Commun. 2014, 50, 5572-5575.

(25) Ghosh, M.; Singh, K. K.; Panda, C.; Weitz, A.; Hendrich, M. P.; Collins, T. J.; Dhar, B. B.; Sen Gupta, $\mathrm{S}$. Formation of a Room Temperature Stable $\mathrm{Fe}^{\mathrm{V}}(\mathrm{O})$ Complex: Reactivity Toward Unactivated C-H Bonds. J. Am. Chem. Soc. 2014, 136, 9524-9527.

(26) Collins, T. J.; Ryabov, A. D. Targeting of High-Valent Iron-TAML Activators at Hydrocarbons and Beyond. Chem. Rev. 2017, 117, 9140-9162. 
(27) Wang, X.; Peter, S.; Kinne, M.; Hofrichter, M.; Groves, J. T. Detection and Kinetic Characterization of a Highly Reactive Heme-Thiolate Peroxygenase Compound I. J. Am. Chem. Soc. 2012, 134, 12897-12900.

(28) Fan, R.; Serrano-Plana, J.; Oloo, W. N.; Draksharapu, A.; Delgado-Pinar, E.; Company, A.; MartinDiaconescu, V.; Borrell, M.; Lloret-Fillol, J.; García-España, E.; Guo, Y.; Bominaar, E. L.; Que, L.; Costas, M.; Münck, E. Spectroscopic and DFT Characterization of a Highly Reactive Nonheme Fev-Oxo Intermediate. J. Am. chem. Soc. 2018, 140, 3916-3928.

(29) Mondal, B.; Neese, F.; Bill, E.; Ye, S. Electronic Structure Contributions of Non-Heme Oxo-Iron(V) Complexes to the Reactivity. J. Am. Chem. Soc. 2018, 140, 9531-9544.

(30) Lyakin, O. Y.; Zima, A. M.; Samsonenko, D. G.; Bryliakov, K. P.; Talsi, E. P. EPR Spectroscopic Detection of the Elusive $\mathrm{Fe}^{\mathrm{V}}=\mathrm{O}$ Intermediates in Selective Catalytic Oxofunctionalizations of Hydrocarbons Mediated by Biomimetic Ferric Complexes. ACS Catalysis 2015, 5, 2702-2707.

(31) Zima, A. M.; Lyakin, O. Y.; Ottenbacher, R. V.; Bryliakov, K. P.; Talsi, E. P. Dramatic Effect of Carboxylic Acid on the Electronic Structure of the Active Species in Fe(PDP)-Catalyzed Asymmetric Epoxidation. ACS Catalysis 2016, 6, 5399-5404.

(32) Zima, A. M.; Lyakin, O. Y.; Ottenbacher, R. V.; Bryliakov, K. P.; Talsi, E. P. Iron-Catalyzed Enantioselective Epoxidations with Various Oxidants: Evidence for Different Active Species and Epoxidation Mechanisms. ACS Catal. 2017, 7, 60-69.

(33) Oloo, W. N.; Banerjee, R.; Lipscomb, J. D.; Que, L. Equilibrating (L)Fe'll-OOAc and (L)FeV(O) Species in Hydrocarbon Oxidations by Bio-Inspired Nonheme Iron Catalysts Using $\mathrm{H}_{2} \mathrm{O}_{2}$ and $\mathrm{AcOH}$. J. Am. Chem. Soc. 2017, 139, 17313-17326.

(34) White, M. C.; Zhao, J. Aliphatic C-H Oxidations for Late-Stage Functionalization. J. Am. Chem. Soc. 2018, 140, 13988-14009.

(35) Serrano-Plana, J.; Acuña-Parés, F.; Dantignana, V.; Oloo, W. N.; Castillo, E.; Draksharapu, A.; Whiteoak, C. J.; Martin-Diaconescu, V.; Basallote, M. G.; Luis, J. M.; Que, L.; Costas, M.; Company, A. AcidTriggered O-O Bond Heterolysis of a Nonheme Fe ${ }^{I I I}(\mathrm{OOH})$ Species for the Stereospecific Hydroxylation of Strong C-H Bonds. Chem. Eur. J. 2018, 24, 5331-5340.

(36) Klein, J. E. M. N.; Que, L. Biomimetic High-Valent Mononuclear Nonheme Iron-Oxo Chemistry. In Encyclopedia of Inorganic and Bioinorganic Chemistry; Scott, R. A., Ed.; John Wiley \& Sons: 2016, p 1-22.

(37) Rasheed, W.; Draksharapu, A.; Banerjee, S.; Young Jr., V. G.; Fan, R.; Guo, Y.; Ozerov, M.; Nehrkorn, J.; Krzystek, J.; Telser, J.; Que Jr., L. Crystallographic Evidence for a Sterically Induced Ferryl Tilt in a NonHeme Oxoiron(IV) Complex that Makes it a Better Oxidant. Angew. Chem. Int. Ed. 2018, 57, 9387-9391.

(38) Company, A.; Prat, I.; Frisch, J. R.; Mas-Ballesté, D. R.; Güell, M.; Juhász, G.; Ribas, X.; Münck, D. E.; Luis, J. M.; Que, L.; Costas, M. Modeling the cis-Oxo-Labile Binding Site Motif of Non-Heme Iron Oxygenases: Water Exchange and Oxidation Reactivity of a Non-Heme Iron(IV)-Oxo Compound Bearing a Tripodal Tetradentate Ligand. Chem. Eur. J. 2011, 17, 1622-1634.

(39) Anastasi, A. E.; Comba, P.; McGrady, J.; Lienke, A.; Rohwer, H. Electronic Structure of Bispidine Iron(IV) Oxo Complexes. Inorg. Chem. 2007, 46, 6420-6426.

(40) Prakash, J.; Rohde, G. T.; Meier, K. K.; Münck, E.; Que, L. Upside Down! Crystallographic and Spectroscopic Characterization of an $\left[\mathrm{Fe}^{\mathrm{IV}}\left(\mathrm{O}_{\text {syn }}\right)(\mathrm{TMC})\right]^{2+}$ Complex. Inorg. Chem. 2015, 54, $11055-11057$.

(41) Klinker, E. J.; Kaizer, J.; Brennessel, W. W.; Woodrum, N. L.; Cramer, C. J.; Que Jr., L. Structures of Nonheme Oxoiron(IV) Complexes from X-ray Crystallography, NMR Spectroscopy, and DFT Calculations. Angew. Chem. Int. Ed. 2005, 44, 3690-3694.

(42) Company, A.; Sabenya, G.; González-Béjar, M.; Gómez, L.; Clémancey, M.; Blondin, G.; Jasniewski, A. J.; Puri, M.; Browne, W. R.; Latour, J.-M.; Que, L.; Costas, M.; Pérez-Prieto, J.; Lloret-Fillol, J. Triggering the Generation of an Iron(IV)-Oxo Compound and Its Reactivity toward Sulfides by Rull Photocatalysis. J. Am. Chem. Soc. 2014, 136, 4624-4633.

(43) Rasheed, W.; Fan, R.; Abelson, C. S.; Peterson, P. O.; Ching, W. M.; Guo, Y.; Jr., L. Q. Structural Implications of the Paramagnetically Shifted NMR Signals from Pyridine H-Atoms on Synthetic Nonheme $\mathrm{Fe}^{\mathrm{IV}}=\mathrm{O}$ Complexes. J. Biol. Inorg. Chem. 2019, 24, 533-545.

(44) Ching, W.-M.; Zhou, A.; Klein, J. E. M. N.; Fan, R.; Knizia, G.; Cramer, C. J.; Guo, Y.; Que, L. Characterization of the Fleeting Hydroxoiron(III) Complex of the Pentadentate TMC-py Ligand. Inorg. Chem. 2017, 56, 11129-11140.

(45) Duban, E. A.; Bryliakov, K. P.; Talsi, E. P. The Active Intermediates of Non-Heme-Iron-Based Systems for Catalytic Alkene Epoxidation with $\mathrm{H}_{2} \mathrm{O}_{2} / \mathrm{CH}_{3} \mathrm{COOH}$. Eur. J. Inorg. Chem. 2007, 2007, 852-857.

(46) Thibon, A.; England, J.; Martinho, M.; Young Jr., V. G.; Frisch, J. R.; Guillot, R.; Girerd, J.-J.; Münck, E.; Que Jr., L.; Banse, F. Proton- and Reductant-Assisted Dioxygen Activation by a Nonheme Iron(II) Complex to Form an Oxoiron(IV) Intermediate. Angew. Chem. Int. Ed. 2008, 47, 7064-7067.

(47) Park, M. J.; Lee, J.; Suh, Y.; Kim, J.; Nam, W. Reactivities of Mononuclear Non-Heme Iron Intermediates Including Evidence that Iron(III)-Hydroperoxo Species Is a Sluggish Oxidant. J. Am. Chem. Soc. 2006, 128, 2630-2634.

(48) Notice that 9,10-dihydroanthracene-d14 could be synthesized with only a $98 \% \mathrm{D}$ enrichment. If this is taken into account, a much higher KIE should have been obtained. 
(49) Hong, S.; So, H.; Yoon, H.; Cho, K.-B.; Lee, Y.-M.; Fukuzumi, S.; Nam, W. Reactivity comparison of high-valent iron(IV)-oxo complexes bearing $\mathrm{N}$-tetramethylated cyclam ligands with different ring size. Dalton Trans. 2013, 42, 7842-7845.

(50) Price, J. C.; Barr, E. W.; Glass, T. E.; Krebs, C.; Bollinger, J. M. Evidence for Hydrogen Abstraction from $\mathrm{C} 1$ of Taurine by the High-Spin Fe(IV) Intermediate Detected during Oxygen Activation by Taurine: $\alpha$ Ketoglutarate Dioxygenase (TauD). J. Am. Chem. Soc. 2003, 125, 13008-13009.

(51) Bollinger, J. M.; Krebs, C. Stalking intermediates in oxygen activation by iron enzymes: Motivation and method. J. Inorg. Biochem. 2006, 100, 586-605.

(52) Kupper, C.; Mondal, B.; Serrano-Plana, J.; Klawitter, I.; Neese, F.; Costas, M.; Ye, S.; Meyer, F. Nonclassical Single-State Reactivity of an Oxo-Iron(IV) Complex Confined to Triplet Pathways. J. Am. Chem. Soc. 2017, 139, 8939-8949.

(53) Monte Pérez, I.; Engelmann, X.; Lee, Y.-M.; Yoo, M.; Kumaran, E.; Farquhar, E. R.; Bill, E.; England, J.; Nam, W.; Swart, M.; Ray, K. A Highly Reactive Oxoiron(IV) Complex Supported by a Bioinspired $\mathrm{N}_{3} \mathrm{O}$ Macrocyclic Ligand. Angew. Chem. Int. Ed. 2017, 56, 14384-14388.

(54) Mitra, M.; Nimir, H.; Demeshko, S.; Bhat, S. S.; Malinkin, S. O.; Haukka, M.; Lloret-Fillol, J.; Lisensky, G. C.; Meyer, F.; Shteinman, A. A.; Browne, W. R.; Hrovat, D. A.; Richmond, M. G.; Costas, M.; Nordlander, E. Nonheme $\mathrm{Fe}(\mathrm{IV}) \mathrm{Oxo}$ Complexes of Two New Pentadentate Ligands and Their Hydrogen-Atom and Oxygen-Atom Transfer Reactions. Inorg. Chem. 2015, 54, 7152-7164.

(55) Kaizer, J.; Klinker, E. J.; Oh, N. Y.; Rohde, J.-U.; Song, W. J.; Stubna, A.; Kim, J.; Münck, E.; Nam, W.; Que, L. Nonheme Felv Complexes That Can Oxidize the $\mathrm{C}-\mathrm{H}$ Bonds of Cyclohexane at Room Temperature. J. Am. Chem. Soc. 2004, 126, 472-473.

(56) Biswas, A. N.; Puri, M.; Meier, K. K.; Oloo, W. N.; Rohde, G. T.; Bominaar, E. L.; Münck, E.; Que, L. Modeling TauD-J: A High-Spin Nonheme Oxoiron(IV) Complex with High Reactivity toward C-H Bonds. J. Am. Chem. Soc. 2015, 137, 2428-2431.

(57) Tanko, J. M.; Friedline, F.; Suleman, N. K.; Jr., N. C. tert-Butoxyl as a Model for Radicals in Biological Systems: Caveat Emptor. J. Am. Chem. Soc. 2001, 123, 5808-5809.

(58) Finn, M.; Friedline, R.; Suleman, N. K.; Wohl, C. J.; Tanko, J. M. Chemistry of the t-Butoxyl Radical: Evidence that Most Hydrogen Abstractions from Carbon are Entropy-Controlled. J. Am. Chem. Soc. 2004, 126, 7578-7584.

(59) Pattanayak, S.; Jasniewski, A. J.; Rana, A.; Draksharapu, A.; Singh, K. K.; Weitz, A.; Hendrich, M.; Que, L.; Dey, A.; Sen Gupta, S. Spectroscopic and Reactivity Comparisons of a Pair of bTAML Complexes with $\mathrm{Fe}^{\mathrm{V}}=\mathrm{O}$ and $\mathrm{Fe}^{\mathrm{IV}}=\mathrm{O}$ Units. Inorg. Chem. 2017, 56, 6352-6361.

(60) Oszajca, M.; Franke, A.; Drzewiecka-Matuszek, A.; Brindell, M.; Stochel, G.; van Eldik, R. Temperature and Pressure Effects on $\mathrm{C}-\mathrm{H}$ Abstraction Reactions Involving Compound I and II Mimics in Aqueous Solution. Inorg. Chem. 2014, 53, 2848-2857.

(61) Bell, S. R.; Groves, J. T. A Highly Reactive P450 Model Compound I. J. Am. Chem. Soc. 2009, 131, 9640-9641.

(62) Krebs, C.; Price, J. C.; Baldwin, J.; Saleh, L.; Green, M. T.; Jr., J. M. B. Rapid Freeze-Quench ${ }^{57 F e}$ Mössbauer Spectroscopy: Monitoring Changes of an Iron-Containing Active Site during a Biochemical Reaction. Inorg. Chem. 2005, 44, 742-757.

(63) Sastri, C. V.; Lee, J.; Oh, K.; Lee, Y. J.; Lee, J.; Jackson, T. A.; Ray, K.; Hirao, H.; Shin, W.; Halfen, J. A.; Kim, J.; Que, L.; Shaik, S.; Nam, W. Axial ligand tuning of a nonheme iron(IV)-oxo unit for hydrogen atom abstraction. Proc. Natl. Acad. Sci. U.S.A. 2007, 104, 19181-19186.

(64) Company, A.; Gómez, L.; Costas, M. Bioinspired Non-heme Iron Catalysts in C-H and C=C Oxidation Reactions. In Iron-Containing Enzymes; Visser, S. P. d., Kumar, D., Eds.; RSC Publishing: Cambridge, 2011.

(65) Mader, E. A.; Davidson, E. R.; Mayer, J. M. Large Ground-State Entropy Changes for Hydrogen Atom Transfer Reactions of Iron Complexes. J. Am. Chem. Soc. 2007, 129, 5153-5166.

(66) Evans, M. G.; Polanyi, M. Inertia and driving force of chemical reactions. Trans. Faraday Soc. 1938, 34, 11-24.

(67) Wang, D.; Zhang, M.; Bühlmann, P.; Que, L. Redox Potential and C-H Bond Cleaving Properties of a Nonheme Felv $=\mathrm{O}$ Complex in Aqueous Solution. J. Am. Chem. Soc. 2010, 132, 7638-7644.

(68) Usharani, D.; Lacy, D. C.; Borovik, A. S.; Shaik, S. Dichotomous Hydrogen Atom Transfer vs ProtonCoupled Electron Transfer During Activation of $X-H$ Bonds $(X=C, N, O)$ by Nonheme Iron-Oxo Complexes of Variable Basicity. J. Am. Chem. Soc. 2013, 135, 17090-17104.

(69) Mittra, K.; Green, M. T. Reduction Potentials of P450 Compounds I and II: Insight into the Thermodynamics of C-H Bond Activation. J. Am. Chem. Soc. 2019, 141, 5504-5510.

(70) Postils, V.; Company, A.; Solà, M.; Costas, M.; Luis, J. M. Computational Insight into the Mechanism of Alkane Hydroxylation by Non-heme Fe(PyTACN) Iron Complexes. Effects of the Substrate and Solvent. Inorg. Chem. 2015, 54, 8223-8236.

(71) Wang, Y.; Janardanan, D.; Usharani, D.; Han, K.; Que, L.; Shaik, S. Nonheme Iron Oxidant Formed in the Presence of $\mathrm{H} 2 \mathrm{O} 2$ and Acetic Acid Is the Cyclic Ferric Peracetate Complex, Not a Perferryloxo Complex. ACS Catal. 2013, 3, 1334-1341. 
(72) Chen, H.; Lai, W.; Shaik, S. Exchange-Enhanced H-Abstraction Reactivity of High-Valent Nonheme Iron(IV)-Oxo from Coupled Cluster and Density Functional Theories. J. Phys. Chem. Lett. 2010, 1, 1533-1540.

(73) Hirao, H.; Kumar, D.; Que, L.; Shaik, S. Two-State Reactivity in Alkane Hydroxylation by Non-Heme Iron-Oxo Complexes. J. Am. Chem. Soc. 2006, 128, 8590-8606.

(74) Groves, J. T.; Adhyam, D. V. Hydroxylation by cytochrome P-450 and metalloporphyrin models. Evidence for allylic rearrangement. J. Am. Chem. Soc. 1984, 106, 2177-2181.

(75) Oloo, W. N.; Feng, Y.; Iyer, S.; Parmelee, S.; Xue, G.; Que, L. Cyclohexene as a substrate probe for the nature of the high-valent iron-oxo oxidant in Fe(TPA)-catalyzed oxidations. New J. Chem. 2013, 37, 34113415.

(76) Shul'pin, G. B.; Süss-Fink, G.; Smith, J. R. L. Oxidations by the System "Hydrogen Peroxide Manganese(IV) Complex - Acetic Acid" - Part II. Tetrahedron 1999, 55, 5345-5358.

(77) Jiang, Y.; He, X.; Ortiz de Montellano, P. R. Radical Intermediates in the Catalytic Oxidation of Hydrocarbons by Bacterial and Human Cytochrome P450 Enzymes. Biochemistry 2006, 45, 533-542.

(78) Cho, K.-B.; Hirao, H.; Shaik, S.; Nam, W. To rebound or dissociate? This is the mechanistic question in $\mathrm{C}-\mathrm{H}$ hydroxylation by heme and nonheme metal-oxo complexes. Chem. Soc. Rev. 2016, 45, 1197-1210.

(79) Pangia, T. M.; Davies, C. G.; Prendergast, J. R.; Gordon, J. B.; Siegler, M. A.; Jameson, G. N. L.; Goldberg, D. P. Observation of Radical Rebound in a Mononuclear Nonheme Iron Model Complex. J. Am. Chem. Soc. 2018, 140, 4191-4194.

(80) Drummond, M. J.; Ford, C. L.; Gray, D. L.; Popescu, C. V.; Fout, A. R. Radical Rebound Hydroxylation Versus H-Atom Transfer in Non-Heme Iron(III)-Hydroxo Complexes: Reactivity and Structural Differentiation. J. Am. Chem. Soc. 2019, 141, 6639-6650.

(81) Serrano-Plana, J.; Aguinaco, A.; Belda, R.; García-España, E.; Basallote, M. G.; Company, A.; Costas, M. Exceedingly Fast Oxygen Atom Transfer to Olefins via a Catalytically Competent Nonheme Iron Species. Angew. Chem. Int. Ed. 2016, 55, 6310-6314.

(82) Sankaralingam, M.; Lee, Y.-M.; Jeon, S. H.; Seo, M. S.; Cho, K.-B.; Nam, W. A mononuclear manganese(III)-hydroperoxo complex: synthesis by activating dioxygen and reactivity in electrophilic and nucleophilic reactions. Chem. Commun. 2018, 54, 1209-1212.

(83) Kim, S. J.; Latifi, R.; Kang, H. Y.; Nam, W.; de Visser, S. P. Activation of hydrocarbon C-H bonds by iodosylbenzene: how does it compare with iron(IV)-oxo oxidants? Chem. Commun. 2009, 1562-1564.

(84) George, G. N.; EXAFSPAK. Stanford Synchrotron Radiation Laboratory: Stanford Linear Accelerator Center: Stanford, CA, 2000.

(85) Wojdyr, M. Fityk: a general-purpose peak fitting program. J. Appl. Crystallogr. 2010, 43, 1126-1128.

(86) ASTM E1840-96(2007) Standard Guide for Raman Shift Standards for Spectrometer Calibration, A. I., DOI: $10.1520 /$ E1840-96R07.

(87) Menges, F. S.-0. s. s., Version 1.2.10; 2018. http://www.effemm2.de/spectragryph/ accessed on 24/03/2019. 


\section{TOC graphic}

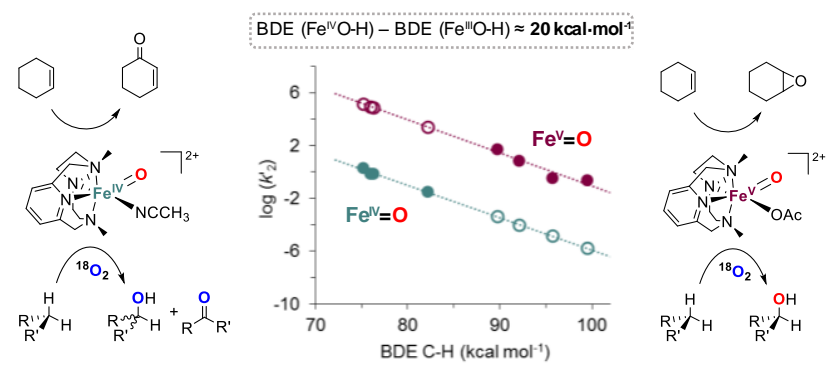

